\title{
仰臥位へ変形可能な体幹前傾式起立補助機の機構設計*
}

\author{
田中英一郎*1，池原 忠明*2，船山 和也*3 \\ 紺谷真紀人 $*^{3}$, 初雁 卓郎 $*^{4}$, 三宅 徳久 $*^{5}$
}

\section{Mechanical Design of a Standing up Assistance Apparatus of Leaning Forward the Upper Body Which Can Be Transformed into a Flat Lying Posture}

\author{
Eiichirou TANAKA*1, Tadaaki IKEHARA, Kazuya FUNAYAMA, \\ Makito KONTANI, Takuro HATSUKARI and Norihisa MIYAKE \\ *1 Shibaura Institute of Technology, 307 Fukasaku, Minuma-ku, Saitama, 337-8570 Japan
}

\begin{abstract}
An apparatus to assist elderly patients to stand up, as well as leaning forward the upper body, has been developed. The mechanism of the apparatus enables to shift the person's center of gravity along an adequate trajectory during the standing up process, so as not to cause strain on the joints of the user's leg. The apparatus also assists a person to alter from standing or sitting posture to lying posture. Although the mechanism has multiple links and joints, only one actuator is required to transform the apparatus between aforementioned three postures. The length of each link of the mechanism has been determined from their effect on the backrest angle when each link in the mechanism length is changed. The torque of the hip and knee joints while using the apparatus can be calculated and compared with the data of a user not using the apparatus. We hypothesize that the output torque of the user while standing is decreased by using the apparatus.
\end{abstract}

Key Words : Welfare Engineering, Medical and Welfare Assistance, Human Engineering, Standing up Assistance, Mechanical Design, Transformation into Standing, Sitting, Lying Postures

\section{1. 緒言}

昨今, 日本は高齢社会となり, 要支援・要介護者の数が増加し, 少子化により労働人口が減少している. また, 介護士の求人数は増加しているが，労働条件や労働環境の不整備により不足している. 要支援・要介護者の中に は，歩行可能であっても起立が障害になり，移動，排泄などの日常動作が介助なしでは困難な方も多い，そのよ うな方を対象に, 多くの機関で起立補助機の開発が進められている(1)(2)が，多くは使用者の腰部を上方に押し上 げることのみで起立補助を行っている．しかし，高齢者には，腰部の押し上げに伴って重心を移動するための体 幹前傾動作を行い, 関節への負担を軽減する起立が望ましい. そこで, 起立中の姿勢と重心の移動に着目し, 起 立困難者の起立時の負担を軽減する装置を開発し，自発的な起立を促進することで QOL 向上を図ることを目標 とする. 第一段階として，立位は可能だが，起立に不安を持つ方に対する補助を行う起立補助椅子の製作を検討 する. 本論文では, 試験機の製作のための機構の具体化と各関節軸に対する力学解析を行ったので報告する.

\section{2. 前傾起立 - 仰臥位型機構の提案}

起立について，健常若年者と健常高齢者を比較したとき，健常若年者は ZMP を中心とし瞬発力を利用した素 早い起立を行うが，高齢者は，筋力低下や平衡感覚の衰えから，このような起立は困難な傾向にある ${ }^{(3)}$.この場 合, 重心を移動するための体幹前傾動作が不可欠となる，そこで筆者らは，重心移動を促す上体の前傾動作と，

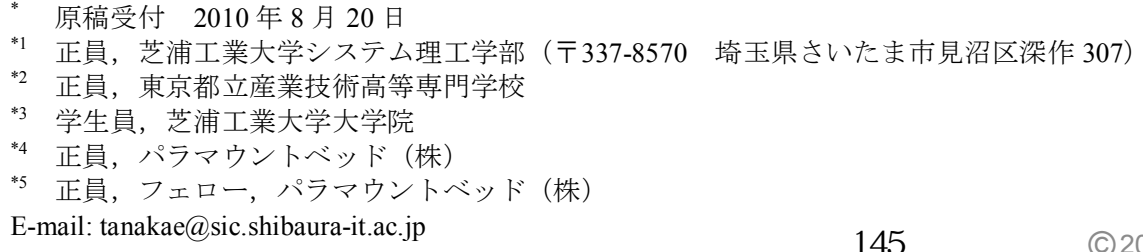


健常者の起立の特徵である(4)，股関節の直線的上昇動作の補助を同時に 1 自由度で行う機構として，チェビシェ フリンク機構およびてこクランク機構を連動させた機構を提案した(4) (図 1). 本機構は, 回転入力の原動節（リ ンク $\mathrm{GK}$ ）を回転させることにより，まずリンク $\mathrm{AB}$ が前傾し，対偶 $\mathrm{B}$ の上昇に伴いリンク $\mathrm{AB}$ が立ち上がる運 動を行い，側面から見てリンク $\mathrm{AB}$ と使用者の体幹を一致させる構造を取り，起立を補助する。原動節が低い位 置にあるので，電動車いす等のアクチュエータの兼用が可能である.また，図 1(b)のように前のめりにもたれか かって使用すれば，トイレやベッドからの起立を補助することができる。しかし，機構内の近似直線運動する図 1 の対偶 $\mathrm{B}$ と使用者の股関節の位置を側面から見て一致させる必要があり, 使用者の左右に機構を配置するため, 装置が大型化する可能性があった. そこで, 使用者の後方に機構部を配置し, 装置を小形化できる機構案として, 図 1 のリンク GK の長さを 0 とし，また，使用者の脚部と接触する可能性のある図 1 のリンク IJ を排除し，各リ ンク長を変化させて作成した前傾起立・仰臥位型機構（図 2）を提案した。対偶 A,B,C,D,E,F,G,I は全て 1 自由度 の回り対偶，2 節対偶であり，対偶 $\mathrm{B}$ は，リンク $\mathrm{GBC}$ 上に存在し，リンク $\mathrm{AB}$ と連結しているが，リンク FI と は連結されていない. 図 2(a)の対偶 $\mathrm{F}$ と対偶 $\mathrm{G}$ を固定中心とし, リンク EF（図 3(b)(c)の黄色のリンク）を紙面 上反時計回りに回転させると，前傾しながら起立する動作と仰臥位から体を持ち上げて起立する動作を実現する (図 3(b)(c)の動作(1)）。このとき, 機構は使用者の背後にあるため, 図 2 機構内の対偶 B は固定中心 $\mathrm{G}$ を心と した円弧運動を行う。しかし，使用者の背面に沿うリンク $\mathrm{AB}$ が前傾するため，リンク $\mathrm{AB}$ と使用者の股関節の 位置関係を調整することで股関節を直線運動させることができる（4 章にて後述する）。また，起立状態からリ ンク EF を図 3(b)(d)紙面上時計回りに回転させると，直接仰臥位に変形する（図 3(b)(d)の動作(2)）。さらに，図 2(b)のように座位時の機構姿勢でリンク GBC を固定して，対偶 C と対偶 I を固定中心とし，固定中心 I 回りにリ ンク FI を図 2(b)において左回転させ，対偶 F を前方に摇動させると，座位から仰臥位への変形も可能である（図 3(b)(e)の動作(3)）。本機構は，全機構が使用者の裏側にあるため（ただし仰臥位時は両脇に対偶 F が残る），使 用者の下腿長に合わせた装置の高さ調整も容易に可能である.また, 図 2(a)の機構と連動した足部持上げ機構 (図 4) を追加し, 1 自由度で, すなわち駆動用アクチュエータ 1 つでフルフラットへの変形を実現可能な構造とした. アクチュエータ 1 つでこれらの変形を実現する場合，低コスト化，モータ使用時の電気系統・制御の簡素化等の 利点がある。 なお，本論文では，本装置開発の第 1 段階として，本機構の最大の特長である体幹前傾起立補助に ついて考察する.
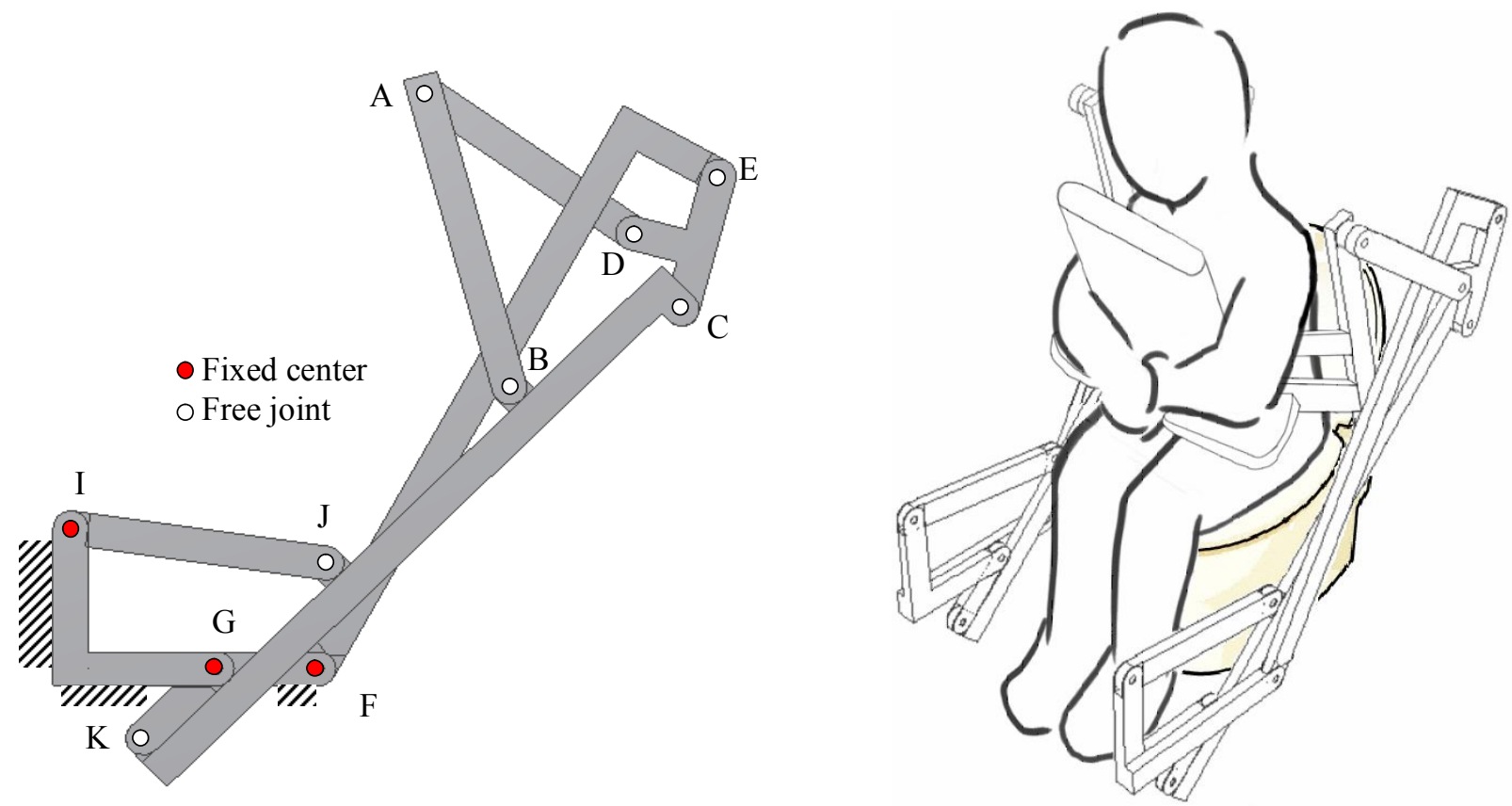

(a) Located relation of each joint

(b) Usage image of the link mechanism (Example: in the lavatory) 


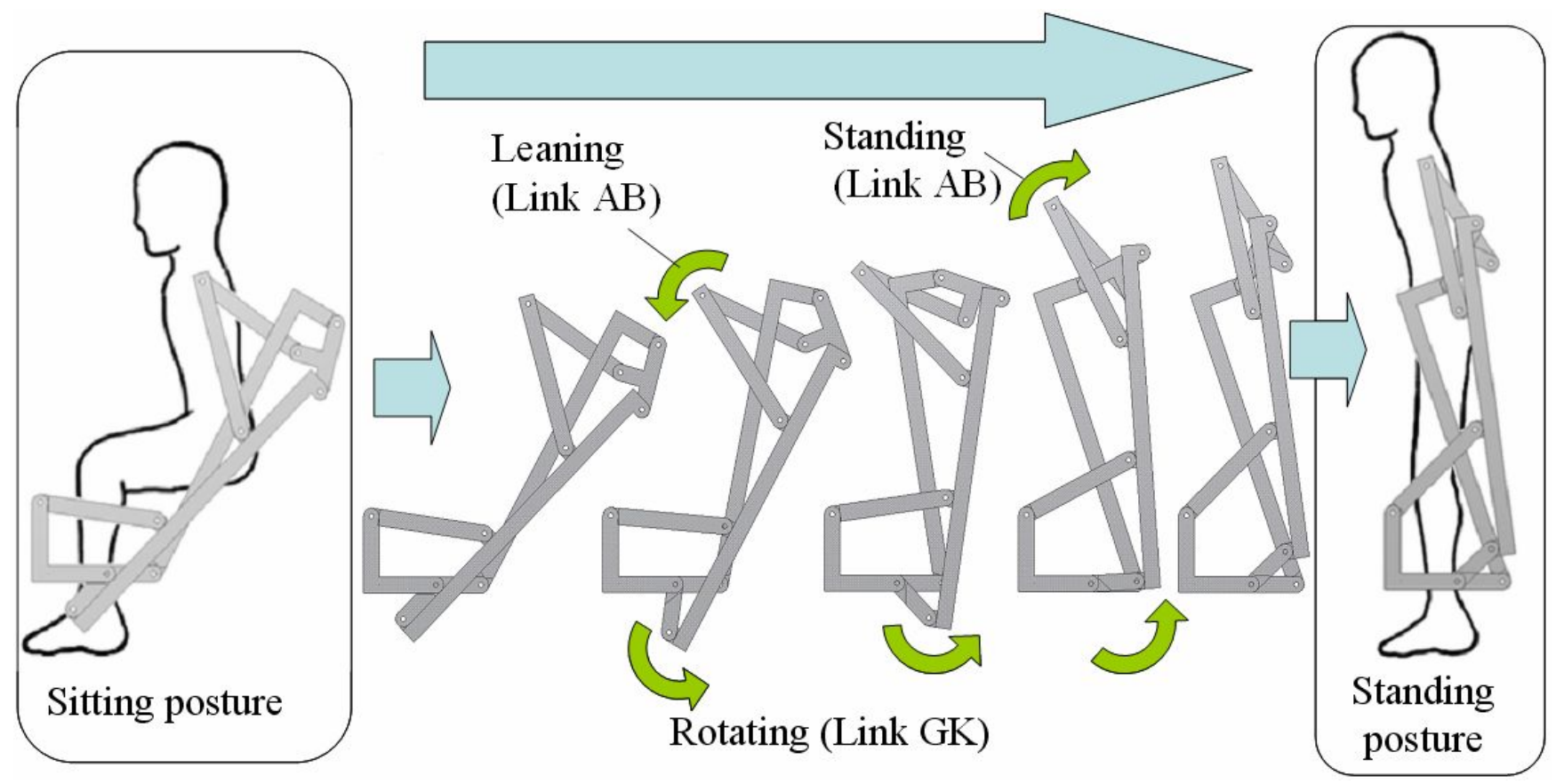

(c) Transformation from sitting into standing posture as well as leaning forward the upper body

Fig. 1 Link mechanism (previous proposed)

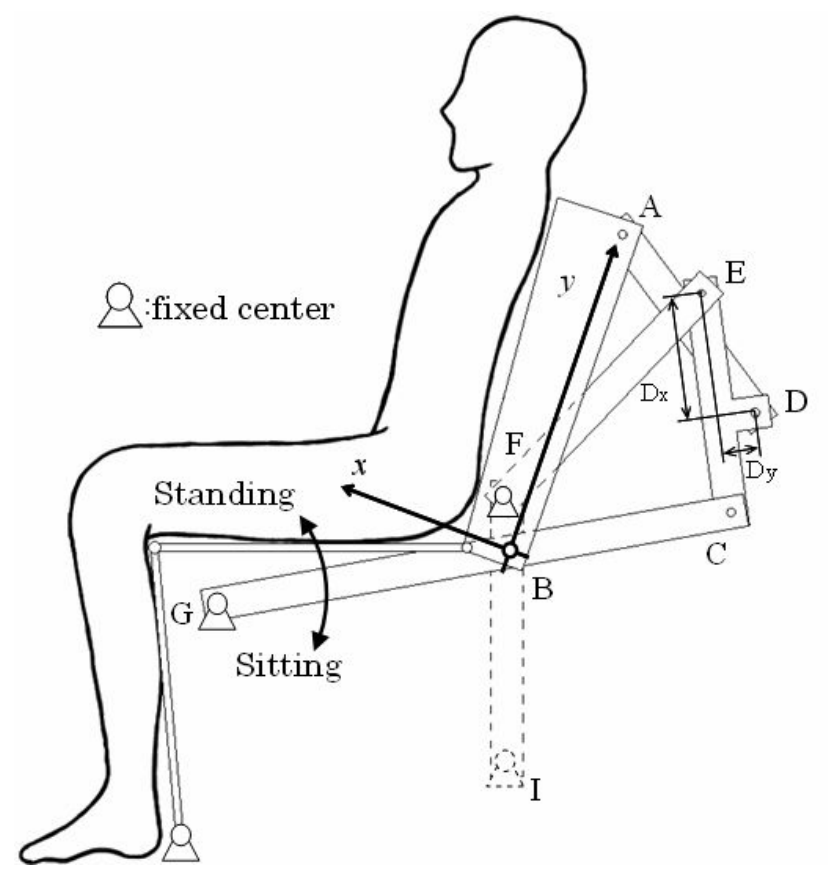

(a) Transformation between sitting and standing

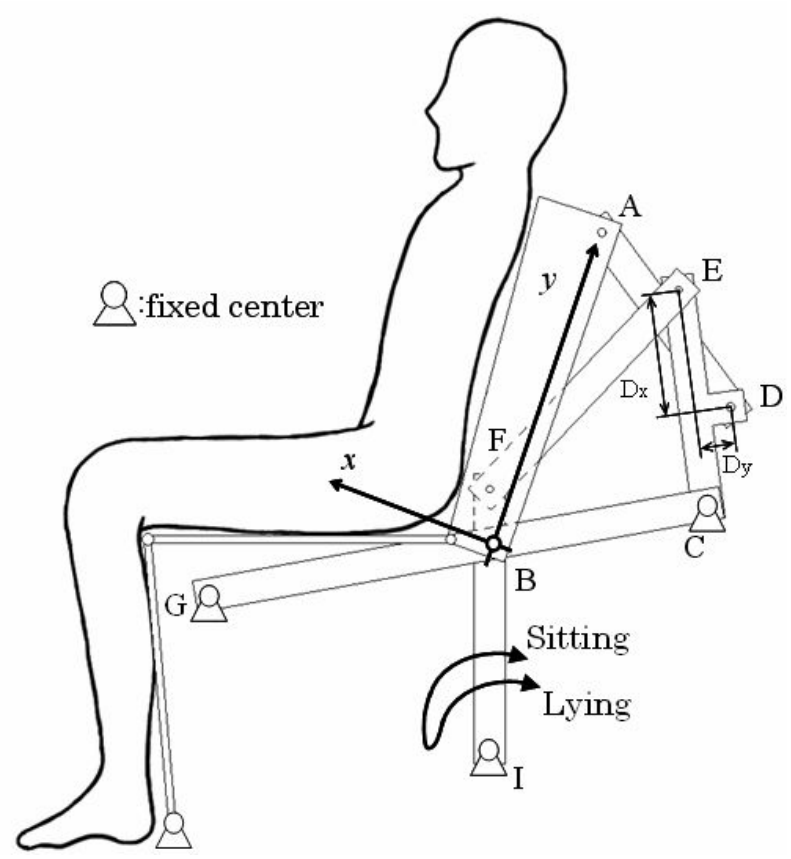

(b) Transformation between sitting and lying

Fig. 2 Located relation of each joint of the link mechanism (newly proposed) 


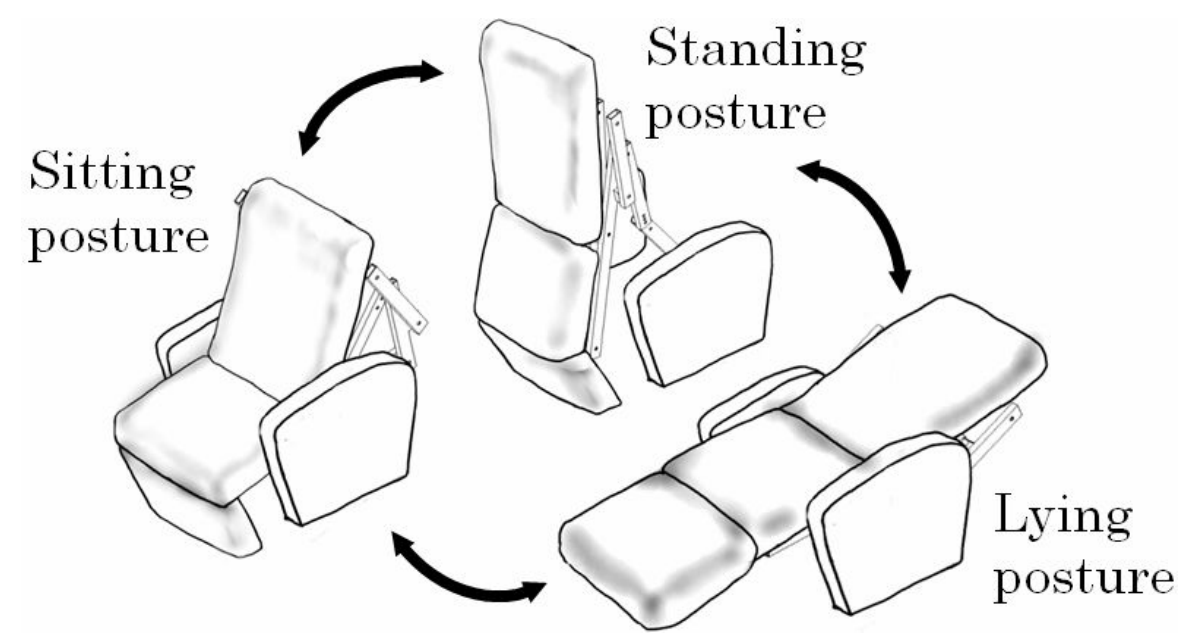

(a) Usage image

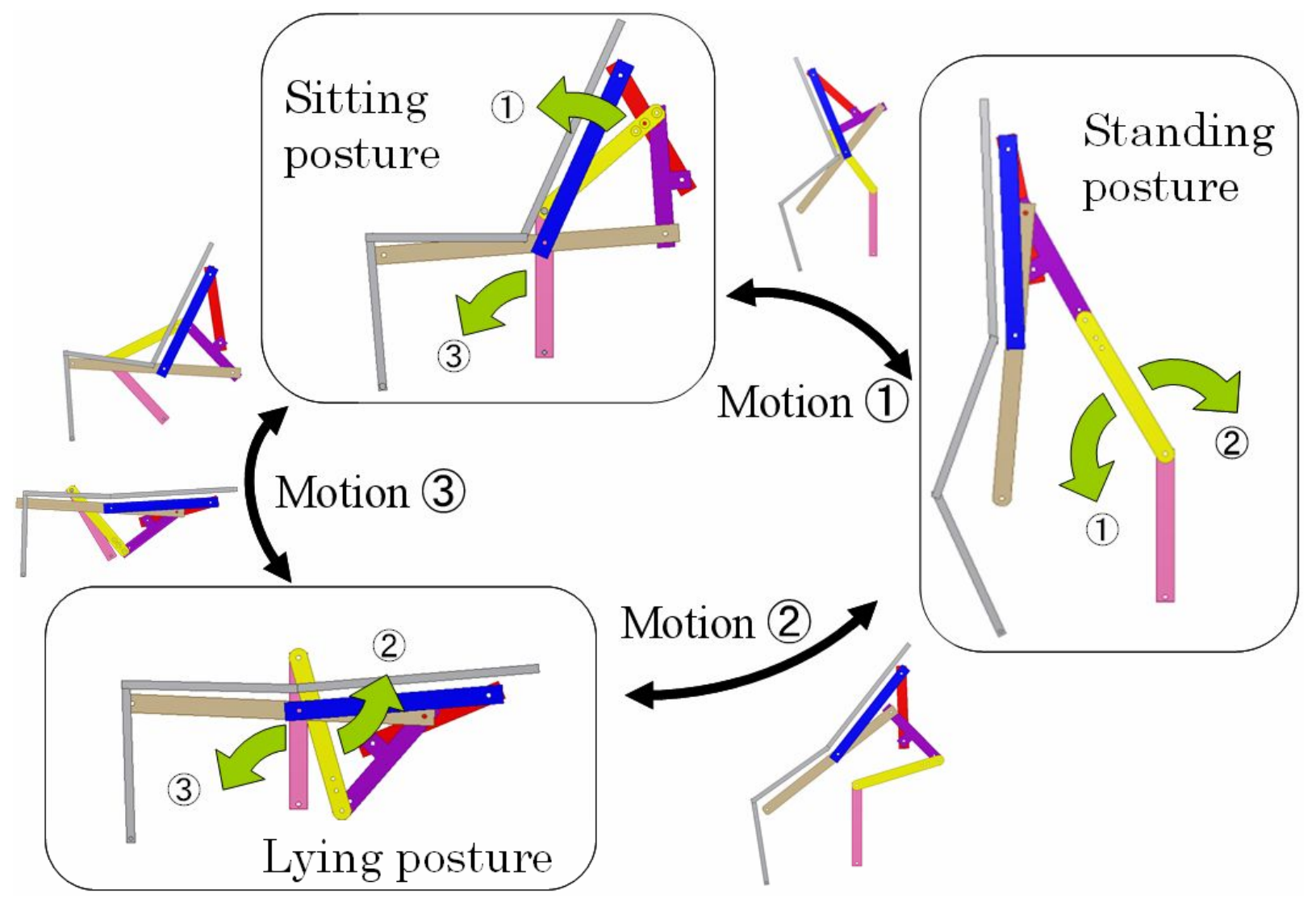

(b) Transformation into sitting, standing, lying postures
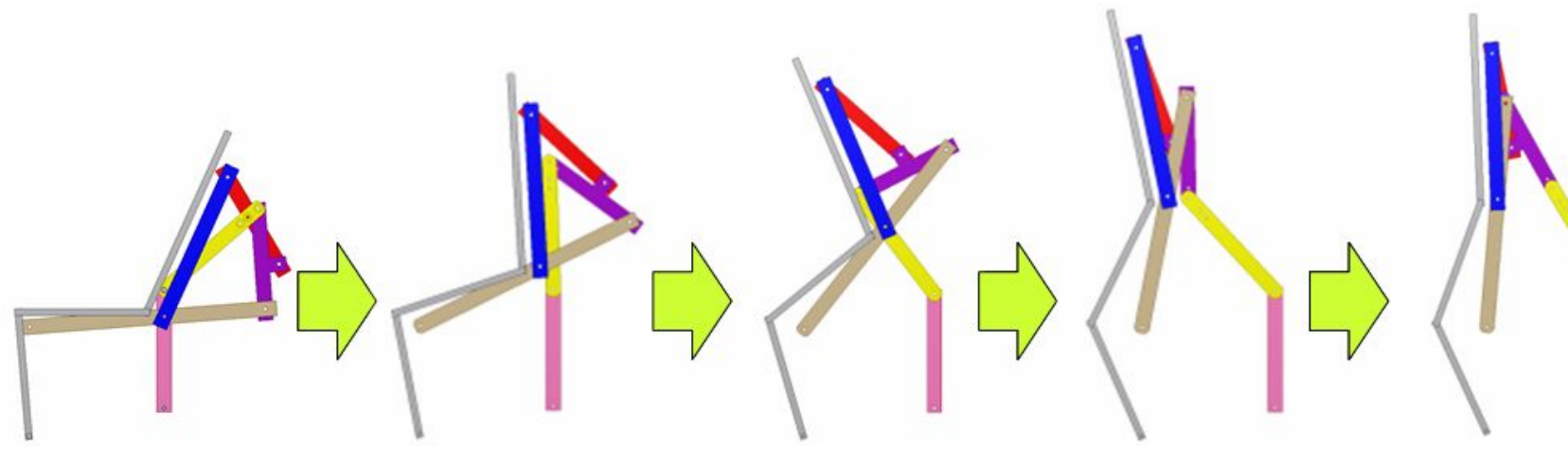

(c) Transformation from sitting to standing (Motion (1) 


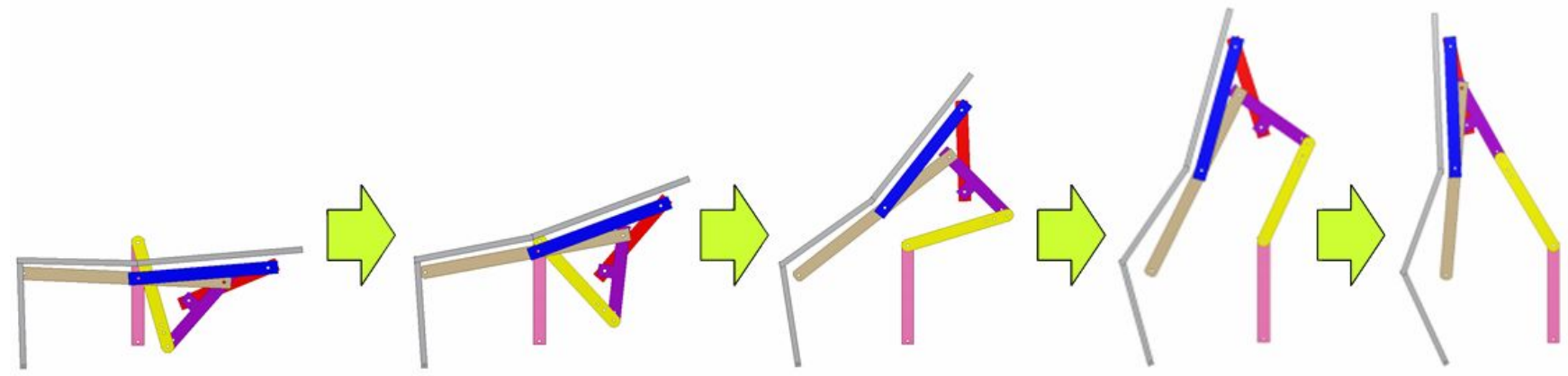

(d) Transformation from lying to standing (Motion (2))

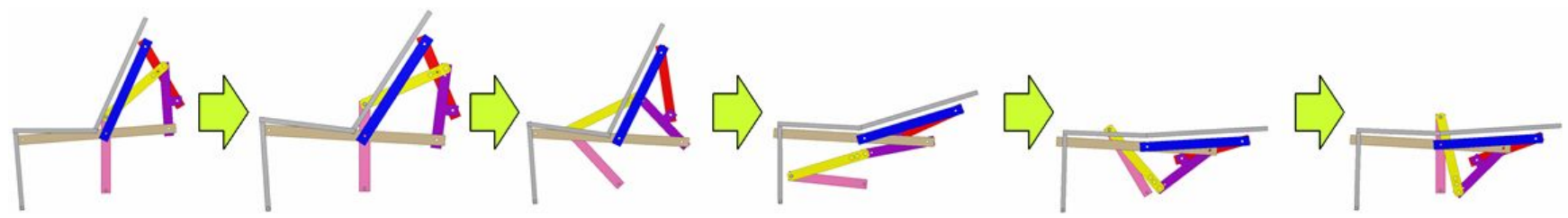

(e) Transformation from sitting to lying (Motion (3)

Fig. 3 Link mechanism (newly proposed)

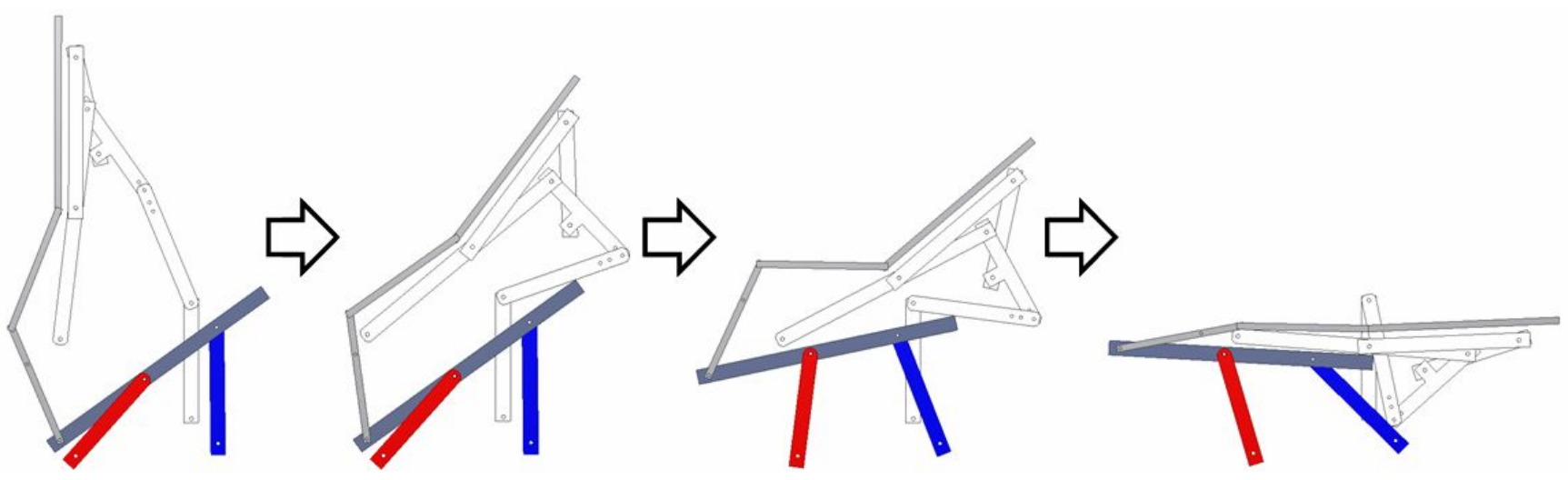

Fig. 4 The mechanism of the footrest

\section{3. 高齢者の起立に適した目標起立姿勢の検討}

本機構の設計にあたり, 補助の目標とする起立姿勢を検討する。人体の各部位の寸法平均值 ${ }^{(5)}$ と重心位置 ${ }^{(6)}$, 質量比 ${ }^{(6)}$ を用いた人体モデルを作成し，文献(7)にある健常若年者および健常高齢者の足・膝・股関節角度変化デ 一タを用いて着座から起立までの姿勢を算出し，そのときの全身での重心位置の推移の軌道を求めた（図 5）. また，足長寸法から爪先および踵の位置を求め，その間を足底面（ただし，今回は 2 次元での解析のため前後幅 のみ考慮）として，重心が足底面上に存在し始める重心位置を確認した。まず，健常若年者が無意識に起立した とき（所要時間 $1.3[\mathrm{~s}] ）$ の計算結果は，重心が足底面上に入る前に上昇を始めており（図 5(a)），瞬発力により 動的な運動を行っていることがわかる．瞬発力を利用した素早い動的な起立を行うには，重心に十分な加速度を 与えることができる筋力と，静的に不安定な姿勢でも転倒しない平衡感覚が必要になるため，高齢者には不向き といえる。一方，健常若年者が瞬発力を利用せず静的に起立した場合の重心軌道を求めると，上体を大きく前傾 させ，重心が足底面上に移動したと同時にほぼ垂直に起立していることが確認できる（図 5(b)）。この若年者は， 静的に動作して平衡感覚を利用する必要はなくなったものの，筋力に頼って垂直方向に起立している．しかし， 同様に健常高齢者の重心の軌道を算出すると（図 5(c)），前方に弧を描くように移動しており，健常若年者の静 的な起立の結果とは差異があった。この結果は，図 5(b)よりも若干所要時間が短縮されており，重心の慣性力に よる反動を使用していると考えられる，すなわち，前方に上体を前傾させたときに発生する前方下向きの重心の 慣性力を，タイミングよく股・膝関節を伸展させることによって，急激な加速度を発生させることなく効率的に 
上向きに変換している，高齢者は，若年者に比べて筋力が低いだけでなく，平衡感覚に頼ることも難しいため， 筋力を最小限に使用し，かつ安定した起立の技能を身につける必要があり，この伸展のタイミングが，高齢者が 楽に起立寸るためのスキルと考える，そこで本研究では，以上の考察より，体幹の前傾を補助する際に，起立中 の重心軌道が前方に弧を描く姿勢をとるよう椅子が動作することを目標とした.

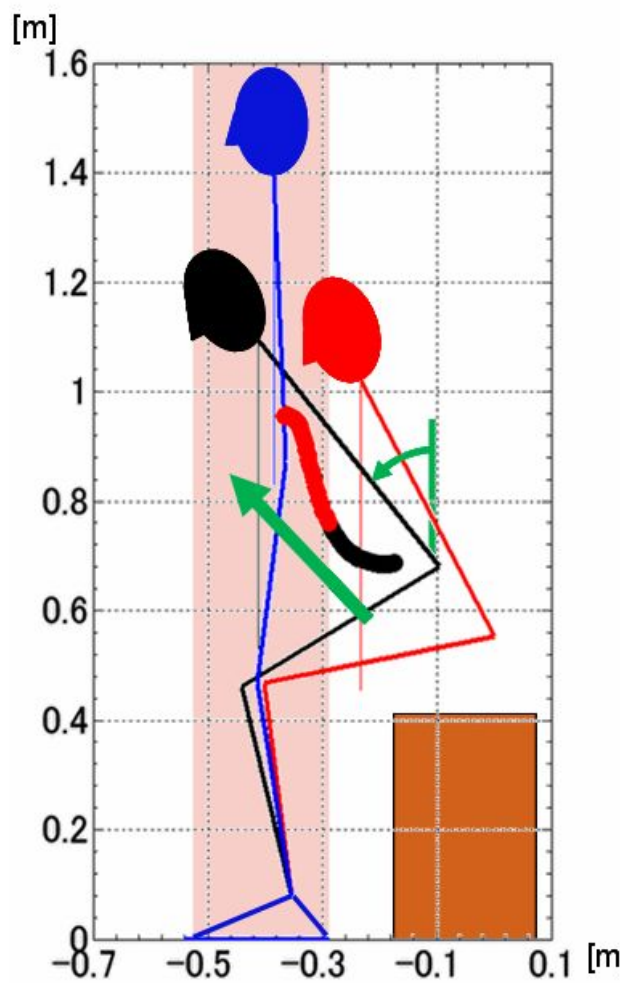

(a) Young people: $1.3[\mathrm{~s}]$

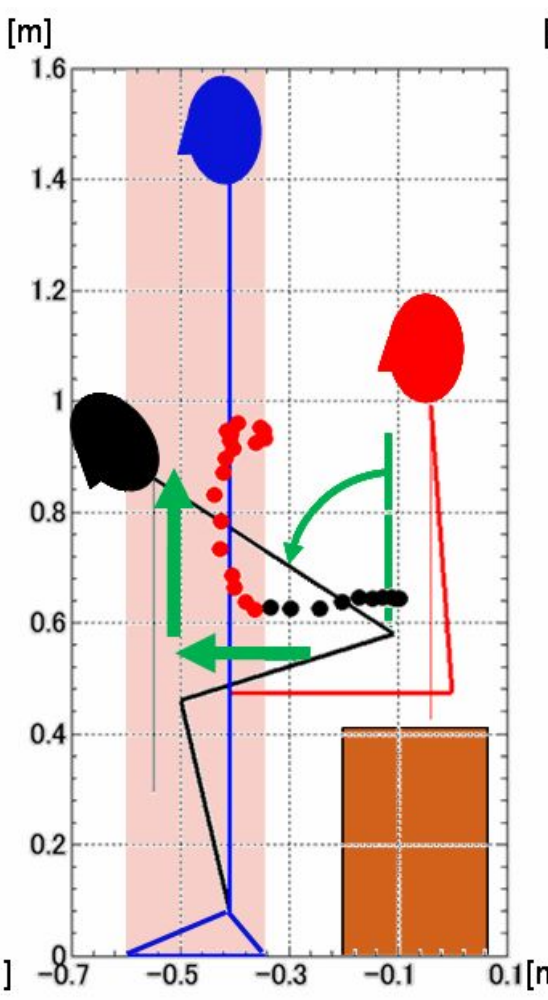

(b) Young people: $2.4[\mathrm{~s}]$ [m]

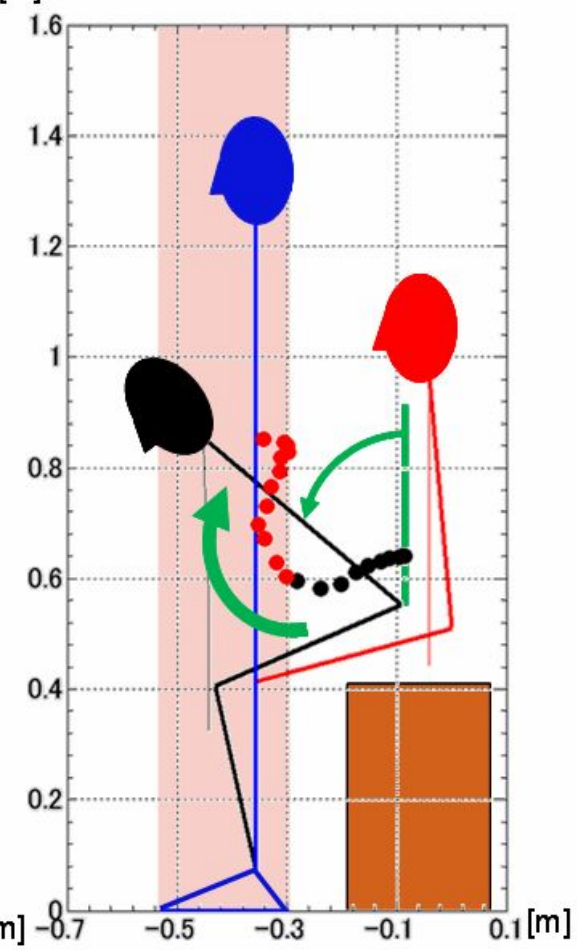

(c) Elderly patient: $2.2[\mathrm{~s}]$

Fig. 5 Trajectory of center of gravity (young people and elderly patient)

\section{4. 前傾起立 ·仰臥位型機構の設計}

\section{$4 \cdot 1$ 背もたれの前傾角度に注目したリンク長の決定}

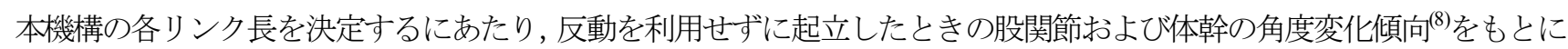
検討する. 前述の起立時の股関節角度および体幹角度計測結果の間の領域に, 背もたれ（図 2(a)リンク $\mathrm{AB}$ ）の角度変化が 入ることを条件とした. また，着座一起立間動作の位相を 100 [\%]としたときの位相 60 [\%]近傍で最も深く前傾するため, 背もたれの前傾のピークが位相 60 [\%]近傍に来ることを条件とした．本装置は，使用者の自立促進を目的とすることや安 全面の考慮から，起立を位相 100 [\%]までは補助せず，起立終期では本人の意思で起立するものとする．その際，起立が困 難な高齢者は膝伸展筋力が低下している(9)ことを想定し，補助終了時には，膝関節角度が力を発揮しやすい角度である 60 $[\mathrm{deg}]$ 付近 ${ }^{(10)}$ になるよう設定した.

以上の 3 つ条件を満たすリンク長を求めるため, 背もたれの角度に影響を与えるリンク $\mathrm{AB}, \mathrm{AD}, \mathrm{EF}$ の長さ, リンク $\mathrm{GBC}$ 上の $\mathrm{BC}$ 間と $\mathrm{BG}$ 間の長さ，リンク $\mathrm{CDE}$ 上の $\mathrm{CE}$ 間の長さ，および軸 $\mathrm{D}$ の位置(図 2(a)上の $\mathrm{Dx}, \mathrm{Dy})$ を個々に延長し， 固定中心 $\mathrm{G}$ 回りにリンク $\mathrm{GBC}$ を等速回転 (図 2(a)では反時計回り) したときの背もたれの前傾角度の変化傾向（背もたれ 角度の初期角度，最前傾角度，最前傾角度時の位相 [\%]）を把握した. 各リンク長を延長していくと，リンク $\mathrm{AB}$ と $\mathrm{EF}$ は 初期角度が図 2(a)の時計回り方向に増加し, リンク $\mathrm{AD}$ は最前傾角度が大きくなる傾向を示した. これらの結果をもとに, 上記 3 条件を満たすリンク長を 3 サイズ決定した. 身長 $170[\mathrm{~cm}]$ 向け L サイズ, 身長 $155[\mathrm{~cm}]$ 向け M サイズ, 身長 $140[\mathrm{~cm}]$ 向け $\mathrm{S}$ サイズの 3 段階に変更できるよう設計した。 決定した各リンク長を図 6 に示す. サイズの変更は 2 箇所のリンク長 （リンク $\mathrm{CE} ， \mathrm{EF}$ ） と，固定中心 $\mathrm{G}$ の位置を変更するのみで実現し，同一の機構で幅広い身長差にも対応可能とした．各 サイズでの背もたれの角度変化（図 7(a)の Backrest angle）と，文献 ${ }^{(8)} の$ 体幹（図 7(a)の Upper body angle）および股関節（図 
7(a)の Hip joint angle）の角度変化データを図 7 に示寸．装置による補助は，起立の位相 80 [\%]で終了するものとして，背も たれ角度を文献(8)のデータと重ねて表示した。 これより，3 サイズとも設定範囲内に収まり，ピークが 60 [\%]近傍にあるこ とを確認した.

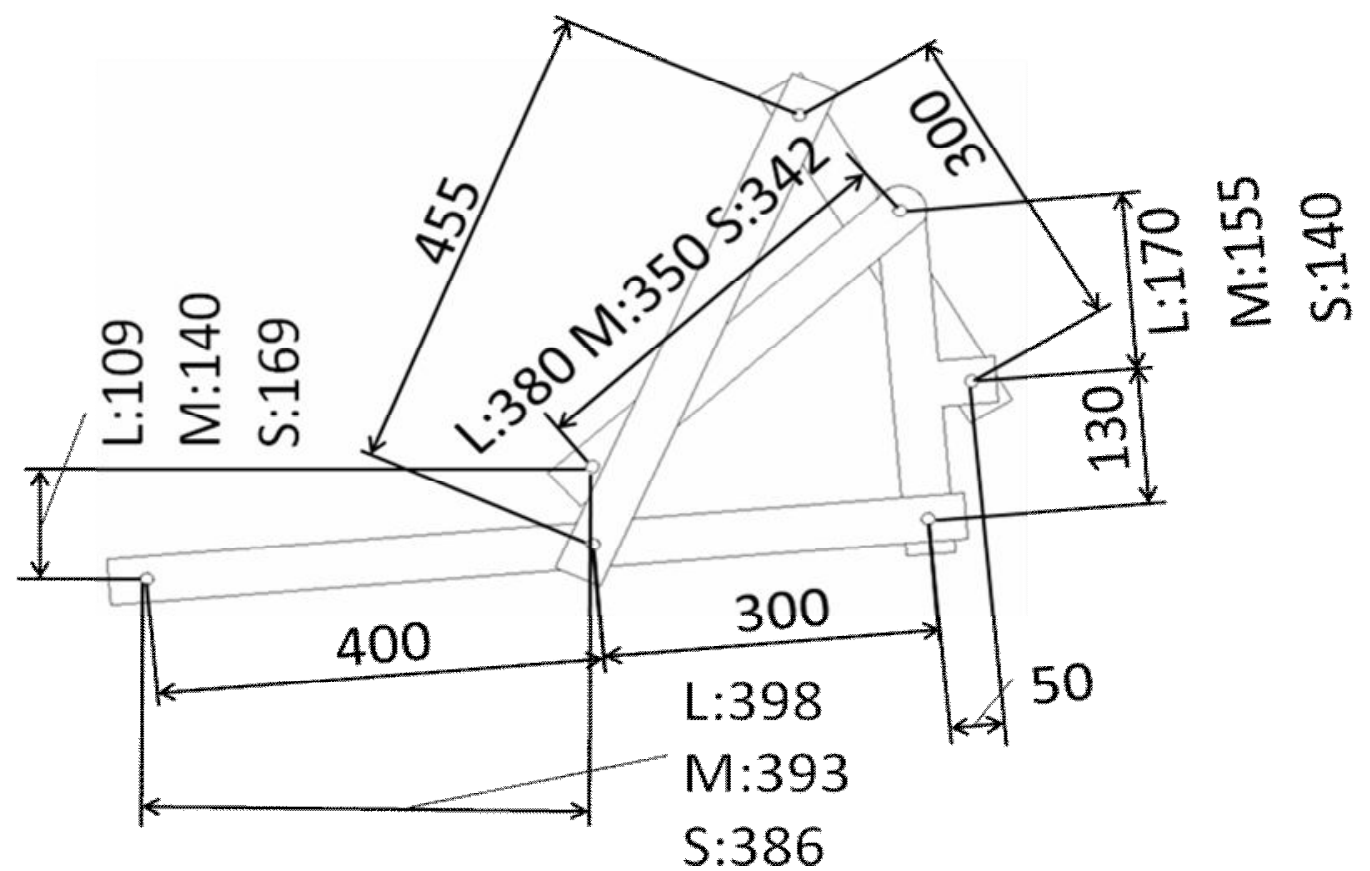

Fig. 6 Each length of the link mechanism of Type II for each size (L, M, S)

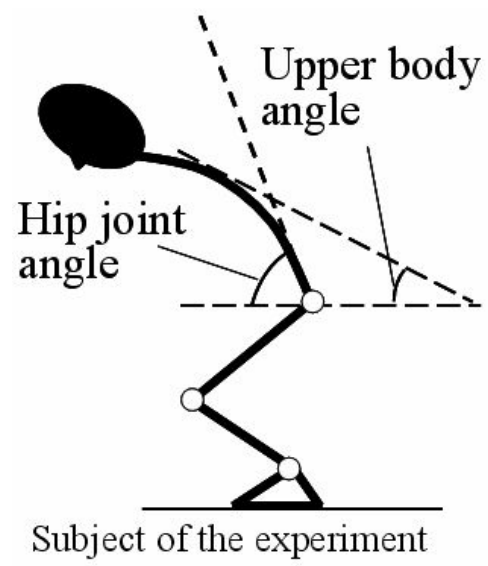

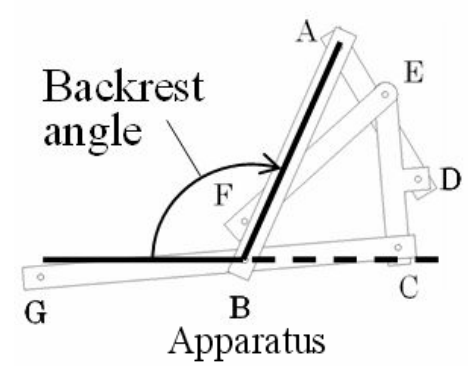

(a) Angle points

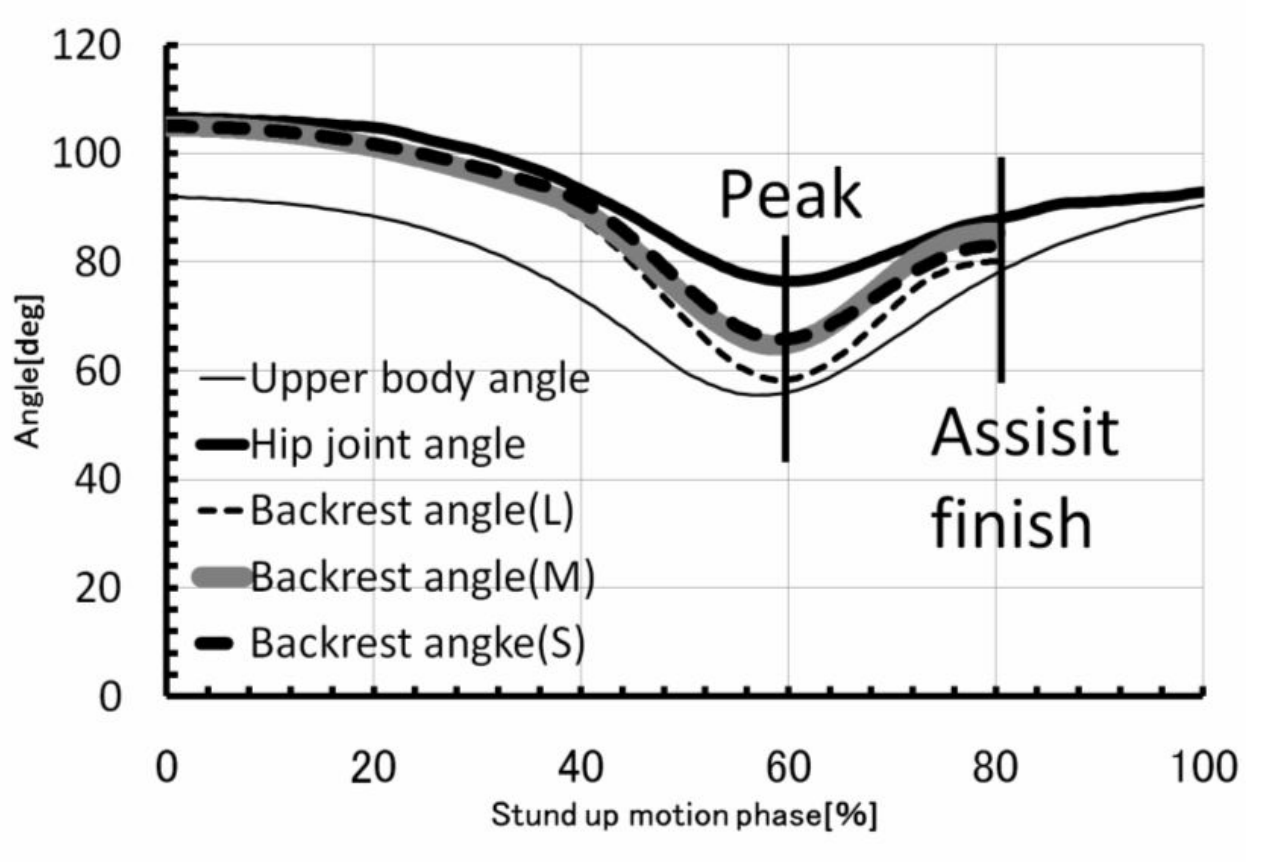

(b) Measured data and calculated data

Fig. 7 Comparison between calculated data of the backrest angle and measured data of the upper body and hip joint angle 


\section{$4 \cdot 2$ 重心・股関節軌道に着目した背支持面高さおよび座面高さの決定}

使用者が，装置に身を委衫ながら起立することを想定すると，機構と使用者の位置関係により，起立中の使用

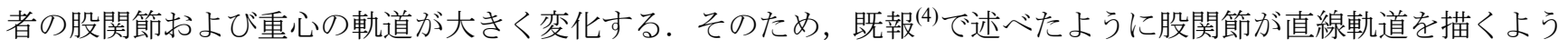
起立すること，また，前述の重心軌道が前方に弧を描くことを目標として，背支持面高さと座面高さを決定した.

図 2 および図 8 に示すように, リンク $\mathrm{AB}$ 内の対偶 $\mathrm{A}, \mathrm{B}$ を通る直線を $y$ 軸に設定し, 対偶 $\mathrm{B}$ を原点として $y$ 軸に垂直な $x$ 軸を設定する. 次に, 股関節位置 $\left(X_{h}, Y_{h}\right)$, 座位殿・転子距離（臀部・背から股関節までの厚さ） $X_{c}$, 座位転子高（臀部・大腿から股関節までの厚さ） $Y_{c}$ を図 8 のように定義し，身体接触面位置 $\left(X_{b}, Y_{b}\right)$ を，

$$
X_{b}=X_{h}-X_{c}, \quad Y_{b}=Y_{h}-Y_{c}
$$

として求める. $X_{b}, Y_{b}$ を, それぞれ $x y$ 軸原点からの背支持面高さ, 座面高さとする. 背もたれや座面のクッショ ンの取り付け位置は，この值を元に決定することができる.

補助を受けて起立したときの使用者の姿勢について, 図 9 に示す人体モデル (データは前述の文献(5)(6)参照) を用い，股関節以上の上半身は背もたれに固定されていると仮定して各関節の角度変化から求め，股関節位置を $x$ 軸方向に-0.2 0.2 [m], $y$ 軸方向に-0.2 0.2 [m] と変化させたときの股関節位置と重心の軌道の変化傾向を確認し た。使用者の身長を $\mathrm{L}$ サイズで想定した $170[\mathrm{~cm}]$, 各関節長さを $\left\{l_{\mathrm{H} 1 \mathrm{~W} 1}, l_{\mathrm{H} 1 \mathrm{~W} 2}, l_{\mathrm{H} 1 \mathrm{~W} 3}, l_{\mathrm{H} 1 \mathrm{~W} 4}, l_{\mathrm{H} 2 \mathrm{~W} 5}, l_{\mathrm{H} 1 \mathrm{H} 2}, l_{\mathrm{H} 3 \mathrm{~W} 6}\right.$, $\left.l_{\mathrm{H} 2 \mathrm{H} 3}\right\}=\{0.71,0.57,0.52,0.25,0.23,0.41,0.23,0.39\}[\mathrm{m}]$, 各質点の質量比を $W_{1}: W_{2}: W_{3}: W_{4}: W_{5}: W_{6}=44:$ 33：101：479：200：107 としたときの，股関節位置（緑線）および重心の軌道（足底面外：黒線，足底面上 : 赤 線）の計算結果を図 10 に示す. 各グラフ下の数值は, 股関節位置の変化量を示している. 股関節軌道および重心 軌道の双方とも，始点と終点の相対位置は変化しないが，軌道の形状が変化することがわかる．股関節軌道，重 心軌道共に同様の傾向があり $x$ 軸方向に移動, 寸なわち背もたれを厚くすると, 起立初期の軌道の傾斜角度が 小さくなり, $y$ 軸方向に移動, すなわち座面を高くすると, 軌道の中間が使用者の向いている前方および下方に 押し出された。 以上の結果より，股関節の軌道を直線に近似し，かつ重心の軌道が比較的大きな円弧状を描く健 常高齢者に近い動きをするよう, 股関節位置を $\left(X_{h}, Y_{h}\right)=(169,54)[\mathrm{mm}]$ とした. また, 文献 ${ }^{(5)} の$ 高齢者の平均值よ り, 座位殿・転子距離 $X_{c}$, 座位転子高 $Y_{c}$ を $\left(X_{c}, Y_{c}\right)=(105,64)[\mathrm{mm}]$ として身体接触面位置を算出すると, 背支持 面高さ $X_{b}$ および座面高さ $Y_{b}$ は， $\left(X_{b}, Y_{b}\right)=(64,-10)[\mathrm{mm}]$ となった．座面は関節 B より低くなるが，背もたれ厚分 前方に配置されるため，機構解析ソフト（Autodesk Inventor Professional, Autodesk 製）にてモデル化し，背もたれ と座面を模擬したリンクを生成し，上記身体接触面位置に配置し，座面および背もたれとリンク $\mathrm{GBC}$ とは空間 的に干渉しないことを確認した.

さらに，各関節用の軸の配置について，空間での干渉を回避するよう構造を検討し，レゴ・マインドストーム を用いて図 11 に示寸模型を製作した. 3 つの姿勢へ変形するには, リンク CDE が他の軸に干渉することなく図 2(a)の 2 次元平面（紙面）上で土180[deg]回転できること, リンク GBC が対偶 F と干渉しないことが必要である. 本模型製作時にこれらの条件を考慮し，3つの姿勢への変形ができることを確認した（図 11(d)）.

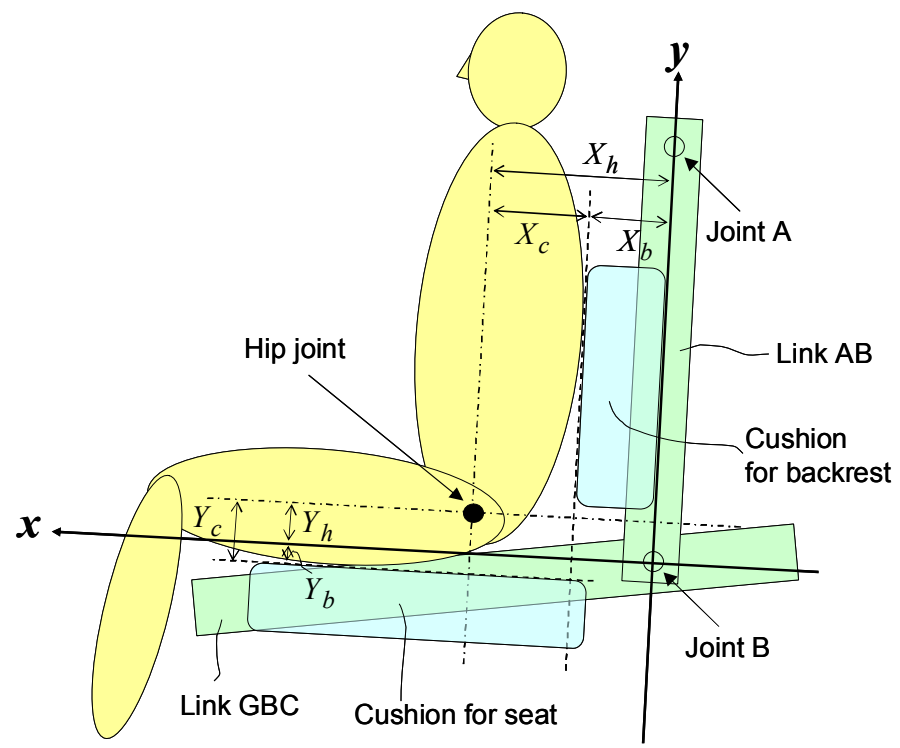

Fig. 8 Definition of each length concern about the cushions for backrest and seat 


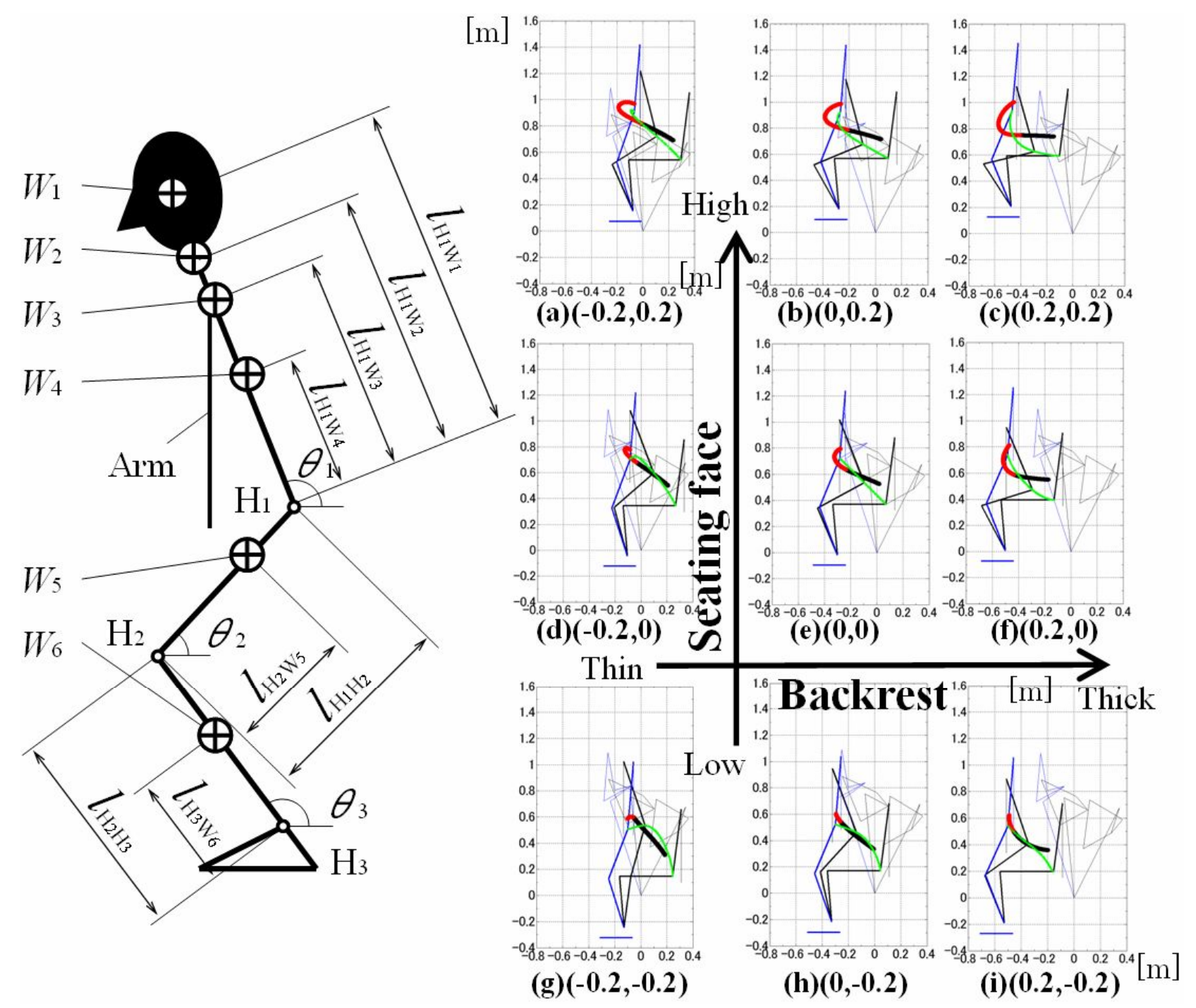

Fig. 9 Human body model

Fig. 10 The variation of the trajectory of center of gravity (Black and red) and hip joint (Green)

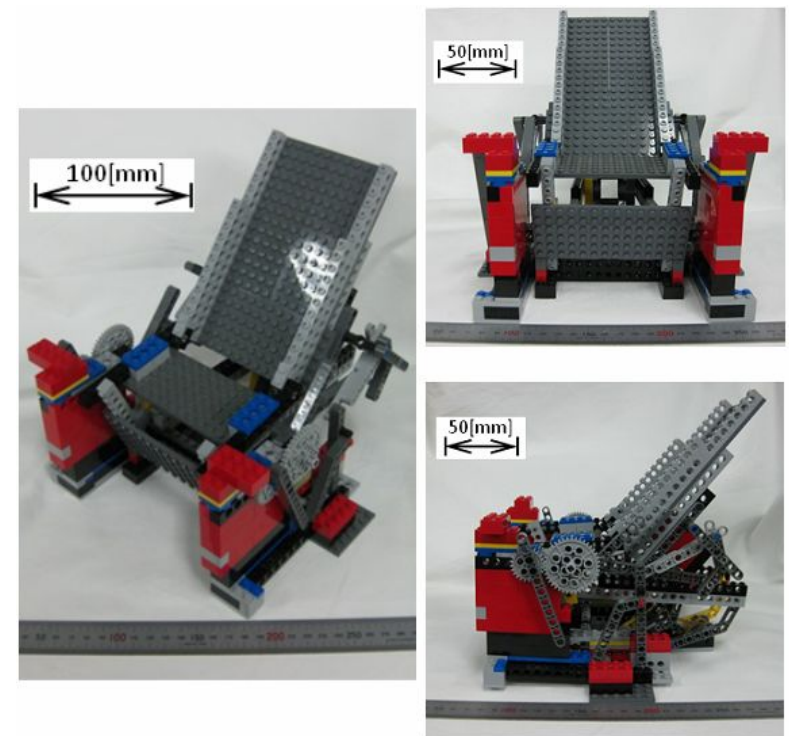

(a) Perspective view (b) Front view (c) Side view

Fig. 11 Model of the standing up assistance apparatus

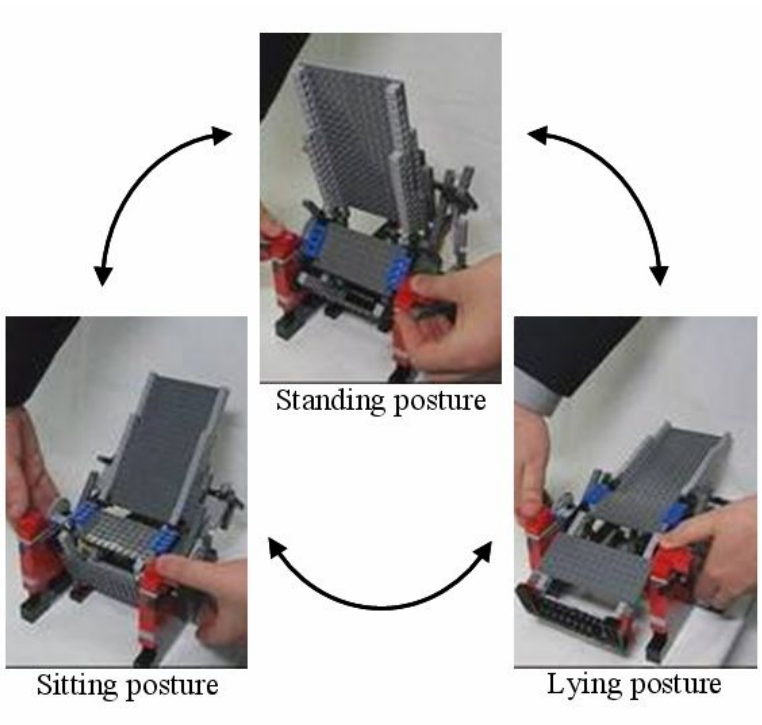

(d) Transformation of three postures with a model 


\section{5. 前傾起立 ·仰臥位型機構の静力学解析}

機構 II を使用して試験機を製作することを想定し，3 つの姿勢に変形する際に各軸にかかるラジアル荷重とそ の向きおよび変化，その姿勢を保持するために入力すべきトルクを静力学により算出した. 人体モデルを二次元 平面上でシリアルリンクとしてモデル化し，その各人体リンクの質点に作用する重力を機構に対する外力として 設定した．また，起立補助時に人体モデルの各質点が機構へ外力として与える方法として，

Case 1：自立して起立することが困難な使用者を想定し，転倒防止のため上半身を背もたれに固定する，

Case 2 : 転倒の心配がない使用者で，体幹前傾時のみ使用者の背中を機構が押寸が，座面に乗っているだけで装

置とは固定しない,

という 2 通りを想定した. Case 1 では，使用者の上体部のリンク，背もたれ，リンク $\mathrm{AB}$ を一体として考え，上 体の各部分（頭部 $W_{1}$, 頸部 $W_{2}$, 腕部 $W_{3}$, 体幹 $W_{4}$ ）の質点を，各部分の重心位置に鉛直下向きにかかる外力と した. Case 2 では，人体モデルの各質点により機構に与える外力は，座面からのみ受けるものとし，また，人体 モデルの大腿部 $\left(W_{5}\right)$ と座面を表すリンクを一体としてモデル化した．ただし本計算では，人体モデルが機構に 及ぼす影響を明確にするため，機構の各リンクの質量は考慮していない.

この外力に対して，機構と人体モデルの全てのリンクが静的なつりあい状態になると仮定したとき，各軸に加 わるラジアル荷重（対偶作用力）と，機構の姿勢を保つために対偶 Gにてリンク GC を押し上げる方向に必要と なるトルク $\tau$ を求めた。 その結果より得た装置動作中に各軸に加わる対偶作用力を考慮して, 機構の各軸径を算

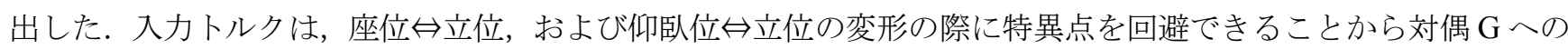
み加えるものとした．機構と人体モデルの全てのリンクについて，各軸に加わる対偶作用力のつりあいを表す方 程式と, 対偶作用力がモーメントとして作用寸る值と入力トルクのつりあいを表す方程式を立て, 合計 21 方程式 をまとめた式(1)より，対偶作用力と入力トルクを求めた.

$$
\boldsymbol{A}(l, \theta) \boldsymbol{f}=\boldsymbol{b}\left(W_{n}, l_{W}, \theta_{W}\right)
$$

ここで, $A(l, \theta) \in \mathrm{R}^{21 \times 21}$ は, 各対偶作用力および入力トルクの係数と, 図 12 に示寸各リンク上の対偶間距離 $l$ と, 各リンク角度 $\theta_{\mathrm{B}}, \theta_{\mathrm{C}}, \theta_{\mathrm{D}}, \theta_{\mathrm{F}}, \phi, \theta_{\mathrm{G}}, \theta_{1}, \theta_{2}, \theta_{3}$ (これらをまとめて $\theta$ と示す) より決定したモーメントアームの值を含む 係数行列である。ここで, 変数 $l$ は, 図 12 の機構の対偶 $\mathrm{A} \sim \mathrm{G}$, 人体モデルの関節の対偶 $\mathrm{H}_{1}, \mathrm{H}_{2}, \mathrm{H}_{3}$, のうちの 2 点間の直線距離, $l_{\mathrm{W}}$ は外力 $W_{n}=W_{1}, W_{2}, \cdots, W_{6}$ の作用点 $\mathrm{W}_{1}, \mathrm{~W}_{2}, \cdots, \mathrm{W}_{6}$ と対偶との直線距離であり，添え字に より 2 点をあらわすものとする. $\boldsymbol{f} \in \mathrm{R}^{21}$ は，各対偶作用力の水平・垂直成分と入力トルク $\tau$ を成分とした未知数 ベクトルとする. $\boldsymbol{b}\left(W_{n}, l_{W}, \theta_{W}\right)=\left\{b_{1}, b_{2}, \cdots, b_{21}\right\}^{\mathrm{T}} \in \mathrm{R}^{21}$ は，使用者の体重として想定した $70[\mathrm{~kg}]$ に，前述の文献よ り得た各部位の質量比をかけた值を頭部 $W_{1}$, 頸部 $W_{2}$, 腕部 $W_{3}$, 体幹 $W_{4}$, 大腿部 $W_{5}$, 下腿部 $W_{6}$ とした外力 $W_{n}=W_{1}$, $W_{2}, \cdots, W_{6}$ と，人体リンク上の各質点（外力）の作用点と回り対偶の中心である永久中心との距離 $l_{\mathrm{W}}=l_{\mathrm{BW} 1}, l_{\mathrm{BW} 2}$, $l_{\mathrm{BW} 3}, l_{\mathrm{BW} 4}, l_{\mathrm{H} 2 \mathrm{~W} 5}, l_{\mathrm{H} 3 \mathrm{~W} 6}$ と, 外力の加わる角度 $\theta_{\mathrm{w}}=\theta_{\mathrm{W} 1}, \theta_{\mathrm{W} 2}, \cdots, \theta_{\mathrm{W} 6}$ の值より生成されるものとする.

各行列についてさらに詳細に示す. まず, 行列 $A$ を, $A_{1}, A_{2}, \cdots, A_{8}$ の 8 つの行列に分割して示寸. $A_{1}, A_{2}, \cdots, A_{8}$ の成分は，次のように表すことができる.

$$
\boldsymbol{A}=\left[\begin{array}{cc}
\boldsymbol{A}_{1} & \boldsymbol{A}_{2} \\
\boldsymbol{A}_{3} & \boldsymbol{A}_{4} \\
\boldsymbol{A}_{5} & \boldsymbol{A}_{6} \\
\boldsymbol{A}_{7} & \boldsymbol{A}_{8}
\end{array}\right] \in \mathrm{R}^{21 \times 21}, \boldsymbol{A}_{1}=\left[\begin{array}{ccccccccccccccc}
1 & 0 & 1 & 0 & 0 & 0 & 0 & 0 & 0 & 0 & 0 & 0 & 0 & 0 & 0 \\
0 & 1 & 0 & 1 & 0 & 0 & 0 & 0 & 0 & 0 & 0 & 0 & 0 & 0 & 0 \\
-1 & 0 & 0 & 0 & 0 & 0 & -1 & 0 & 0 & 0 & 0 & 0 & 0 & 0 & 0 \\
0 & -1 & 0 & 0 & 0 & 0 & 0 & -1 & 0 & 0 & 0 & 0 & 0 & 0 & 0 \\
0 & 0 & -1 & 0 & -1 & 0 & 0 & 0 & 0 & 0 & 0 & 0 & 1 & 0 & 0 \\
0 & 0 & 0 & -1 & 0 & -1 & 0 & 0 & 0 & 0 & 0 & 0 & 0 & 1 & 0 \\
0 & 0 & 0 & 0 & 1 & 0 & 1 & 0 & 1 & 0 & 0 & 0 & 0 & 0 & 0 \\
0 & 0 & 0 & 0 & 0 & 1 & 0 & 1 & 0 & 1 & 0 & 0 & 0 & 0 & 0 \\
0 & 0 & 0 & 0 & 0 & 0 & 0 & 0 & -1 & 0 & 1 & 0 & 0 & 0 & 0 \\
0 & 0 & 0 & 0 & 0 & 0 & 0 & 0 & 0 & -1 & 0 & 1 & 0 & 0 & 0
\end{array}\right] \in \mathrm{R}^{15 \times 10}, \boldsymbol{A}_{2}=\left[\begin{array}{ccccc}
1 & 0 & 0 & \cdots & 0 \\
0 & 1 & 0 & & \\
0 & 0 & 0 & & \vdots \\
\vdots & & & \ddots & \\
0 & & \cdots & & 0
\end{array}\right] \in \mathrm{R}^{6 \times 10},
$$


$\boldsymbol{A}_{3}=\boldsymbol{0} \in \mathrm{R}^{15 \times 4}, \boldsymbol{A}_{4}=\left[\begin{array}{cccccc}-1 & 0 & 1 & 0 & 0 & 0 \\ 0 & -1 & 0 & 1 & 0 & 0 \\ 0 & 0 & -1 & 0 & 1 & 0 \\ 0 & 0 & 0 & -1 & 0 & 1\end{array}\right] \in \mathrm{R}^{6 \times 4}$

$\boldsymbol{A}_{5}=\left[\begin{array}{cccccc}-l_{\mathrm{AB}} \sin \theta_{\mathrm{B}} & l_{\mathrm{AB}} \cos \theta_{\mathrm{B}} & 0 & 0 & 0 & 0 \\ l_{\mathrm{AD}} \sin \theta_{\mathrm{D}} & -l_{\mathrm{AD}} \cos \theta_{\mathrm{D}} & 0 & 0 & 0 & 0 \\ 0 & 0 & l_{\mathrm{BG}} \sin \theta_{\mathrm{G}} & -l_{\mathrm{BG}} \cos \theta_{\mathrm{G}} & l_{\mathrm{CG}} \sin \theta_{\mathrm{G}} & -l_{\mathrm{CG}} \cos \theta_{\mathrm{G}} \\ 0 & 0 & 0 & 0 & 0 & 0 \\ 0 & 0 & 0 & 0 & 0 & 0\end{array}\right.$

$\left.\begin{array}{ccccccccc}0 & 0 & 0 & 0 & 0 & 0 & 0 & 0 & 0 \\ 0 & 0 & 0 & 0 & 0 & 0 & 0 & 0 & 0 \\ 0 & 0 & 0 & 0 & 0 & 0 & 0 & 0 & 1 \\ -l_{\mathrm{CD}} \sin \theta_{\mathrm{C}} & l_{\mathrm{CD}} \cos \theta_{\mathrm{C}} & -l_{\mathrm{CE}} \sin \left(\theta_{\mathrm{C}}-\phi\right) & l_{\mathrm{CE}} \cos \left(\theta_{\mathrm{C}}-\phi\right) & 0 & 0 & 0 & 0 & 0 \\ 0 & 0 & l_{\mathrm{EF}} \sin \theta_{\mathrm{F}} & -l_{\mathrm{EF}} \cos \theta_{\mathrm{F}} & 0 & 0 & 0 & 0 & 0\end{array}\right] \in \mathrm{R}^{15 \times 5}$,

$\boldsymbol{A}_{6}=\left[\begin{array}{ccccc}-l_{\mathrm{BH}_{1}} \sin \theta_{1} & l_{\mathrm{BH}_{1}} \cos \theta_{1} & 0 & \cdots & 0 \\ 0 & 0 & 0 & & 0 \\ \vdots & & & \ddots & \vdots \\ 0 & \cdots & & \cdots & 0\end{array}\right] \in \mathrm{R}^{6 \times 5}, \boldsymbol{A}_{7}=\boldsymbol{0} \in \mathrm{R}^{15 \times 2}, \boldsymbol{A}_{8}=\left[\begin{array}{cccccc}0 & 0 & -l_{\mathrm{H}_{1} \mathrm{H}_{2}} \sin \theta_{2} & l_{\mathrm{H}_{1} \mathrm{H}_{2}} \cos \theta_{2} & 0 & 0 \\ 0 & 0 & 0 & 0 & -l_{\mathrm{H}_{2} \mathrm{H}_{3}} \sin \theta_{3} & l_{\mathrm{H}_{2} \mathrm{H}_{3}} \cos \theta_{3}\end{array}\right] \in \mathrm{R}^{6 \times 2}$.

ここで， $A_{1}, \cdots, A_{4}$ は，機構および人体モデルの各軸に加わる対偶作用力が，つりあい式に関与する場合は 1 （も しくは-1），関与しない場合は 0 が成分として代入される. $A_{5}, \cdots, A_{8}$ は対偶作用力がモーメントとして作用する 值と, 対偶 $\mathrm{G}$ に入力したトルク $\tau$ のつりあい式の係数である. また, $\boldsymbol{A}_{1}$ は機構の各対偶作用力のつりあい式, $A_{2}$ は人体モデルの股関節 $\mathrm{H}_{1}$ とリンク $\mathrm{AB}$ の対偶作用力のつりあい式, $\boldsymbol{A}_{4}$ は人体モデルの膝関節 $\mathrm{H}_{2}$, 足関節 $\mathrm{H}_{3}$ に加 わる対偶作用力のつりあい式の係数行列である. 同様に， $A_{5}$ は機構の各対偶作用力がモーメントとして作用寸る 值と対偶 $\mathrm{G}$ の入力トルクのつりあい式， $\boldsymbol{A}_{6}$ は股関節 $\mathrm{H}_{1}$ とリンク $\mathrm{AB}$ の各対偶作用力がモーメントとして作用す る值のつりあい式, $A_{8}$ は人体モデルの膝・足関節での各対偶作用力がモーメントとして作用する值のつりあい式 の係数行列である. $A_{3}, A_{7}$ は零行列である.

次に, 図 12 の各軸の対偶作用力を $\boldsymbol{F}_{\mathrm{A}}, \boldsymbol{F}_{\mathrm{B}}, \cdots, \boldsymbol{F}_{\mathrm{G}}, \boldsymbol{F}_{\mathrm{H} 1}, \boldsymbol{F}_{\mathrm{H} 2}, \boldsymbol{F}_{\mathrm{H} 3}$ とすると, $\boldsymbol{f}$ は次のように表すことができる.

$$
\boldsymbol{f}=\left\{\begin{array}{llllll}
\boldsymbol{F}_{\mathrm{A}}{ }^{\mathrm{T}} & \boldsymbol{F}_{\mathrm{B}}{ }^{\mathrm{T}} \cdots \boldsymbol{F}_{\mathrm{G}}^{\mathrm{T}} & \boldsymbol{\tau} & \boldsymbol{F}_{\mathrm{H} 1}{ }^{\mathrm{T}} & \boldsymbol{F}_{\mathrm{H} 2}{ }^{\mathrm{T}} & \boldsymbol{F}_{\mathrm{H} 3}{ }^{\mathrm{T}}
\end{array}\right\}^{\mathrm{T}} \in \mathrm{R}^{21},
$$

ただし, $\boldsymbol{F}_{\mathrm{A}}=\left\{F_{\mathrm{A} x}, F_{\mathrm{A} y}\right\}^{\mathrm{T}} \in \mathrm{R}^{2}, \boldsymbol{F}_{\mathrm{B}}=\left\{F_{\mathrm{B} x}, F_{\mathrm{B} y}\right\}^{\mathrm{T}} \in \mathrm{R}^{2}, \boldsymbol{F}_{\mathrm{C}}=\left\{F_{\mathrm{C} x}, F_{\mathrm{C} y}\right\}^{\mathrm{T}} \in \mathrm{R}^{2}, \boldsymbol{F}_{\mathrm{D}}=\left\{F_{\mathrm{D} x}, F_{\mathrm{D} y}\right\}^{\mathrm{T}} \in \mathrm{R}^{2}, \boldsymbol{F}_{\mathrm{E}}=\left\{F_{\mathrm{E} x}, F_{\mathrm{E} y}\right\}^{\mathrm{T}}$ $\in \mathrm{R}^{2}, \boldsymbol{F}_{\mathrm{F}}=\left\{F_{\mathrm{F} x}, F_{\mathrm{F} y}\right\}^{\mathrm{T}} \in \mathrm{R}^{2}, \boldsymbol{F}_{\mathrm{G}}=\left\{F_{\mathrm{G} x}, F_{\mathrm{G} y}\right\}^{\mathrm{T}} \in \mathrm{R}^{2}, \boldsymbol{F}_{\mathrm{H} 1}=\left\{F_{\mathrm{H} 1 x}, F_{\mathrm{H} 1 y}\right\}^{\mathrm{T}} \in \mathrm{R}^{2}, \boldsymbol{F}_{\mathrm{H} 2}=\left\{F_{\mathrm{H} 2 x}, F_{\mathrm{H} 2 y}\right\}^{\mathrm{T}} \in \mathrm{R}^{2}, \boldsymbol{F}_{\mathrm{H} 3}=\left\{F_{\mathrm{H} 3 x}, F_{\mathrm{H} 3 y}\right.$ \}$^{\mathrm{T}} \in \mathrm{R}^{2}$.

最後に, 人体モデルの各質点が外力として及ぼすベクトル $\boldsymbol{b}\left(W_{n}, l_{W}, \theta_{W}\right)=\left\{b_{1}, b_{2}, \cdots, b_{21}\right\}^{\mathrm{T}} \in \mathrm{R}^{21}$ の成分を示す. 各質点は鉛直下向きより， $\theta_{\mathrm{W}}=\theta_{\mathrm{W} 1}, \theta_{\mathrm{W} 2}, \cdots, \theta_{\mathrm{W} 6}=-90[\mathrm{deg}]$ とした。 これにより，外力がモーメントとして作用す る值 $\left(b_{15}, b_{16}, \cdots, b_{21}\right)$ に現れる $\sin \theta_{\mathrm{w}}, \cos \theta_{\mathrm{w}}$ の值は，それぞれ-1，0 とした. Case 1 の場合は,

$\boldsymbol{b}=\left\{\begin{array}{llllllllllllll}0 & W_{1}+W_{2}+W_{3}+W_{4} & 0 & 0 & 0 & 0 & 0 & 0 & 0 & 0 & 0 & W_{5} & 0 & W_{6}\end{array}\right.$

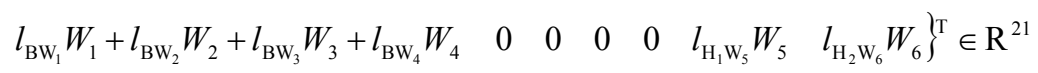

とし，Case 2 の場合は，

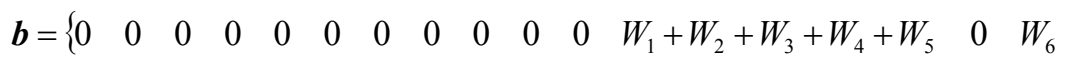

$$
\left.\begin{array}{lllllllll}
0 & 0 & 0 & 0 & 0 & l_{\mathrm{H}_{1} \mathrm{~W}_{1}} W_{1}+l_{\mathrm{H}_{1} \mathrm{~W}_{2}} W_{2}+l_{\mathrm{H}_{1} \mathrm{~W}_{3}} W_{3}+l_{\mathrm{H}_{1} \mathrm{~W}_{4}} W_{4}+l_{\mathrm{H}_{1} \mathrm{~W}_{5}} W_{5} \quad l_{\mathrm{H}_{2} \mathrm{~W}_{6}} W_{6}
\end{array}\right\}^{\mathrm{T}} \in \mathrm{R}^{21}
$$

とした．今回の計算では，使用者の体重を $70[\mathrm{~kg}]$ とし，人体モデルの各部の質量による外力を頭部 $W_{1}=30[\mathrm{~N}]$, 頸部 $W_{2}=23[\mathrm{~N}]$, 腕部 $W_{3}=69[\mathrm{~N}]$, 体幹 $W_{4}=329[\mathrm{~N}]$, 大腿部 $W_{5}=137[\mathrm{~N}]$, 下腿部 $W_{6}=73[\mathrm{~N}]$ としたとき, Case 1 で 
は座面（リンク $\mathrm{H}_{1} \mathrm{H}_{2}$ ）に $137[\mathrm{~N}]$ ，背もたれ（リンク $\mathrm{AB}$ ）に 450 [N]の負荷が加わる，一方，Case 2 では，座面 に $588[\mathrm{~N}]$ の負荷が加わる．これらの負荷を，bによって考慮し，機構の姿勢によらず常に鉛直下向きに加わり， 大きさは一定とした.

以上のように想定した 2 種類の負荷に対してつりあいの式を解き，各軸への対偶作用力と，対偶 $\mathrm{G}$ に入力ず きトルクの大きさを求めた。 また，仰卧位から立位までの動作については，上半身は常に背もたれと接している と仮定し, Case 1 でのみ対偶作用力と入力トルクを求めた。図 13 にCase 1 の座位から立位へ，仰臥位から立位 への変形時, 図 14 にCase 2 の座位から立位への計算結果例を示寸.リニアアクチュエータを使用したとして, 起立補助終了時の最大ストローク $500[\mathrm{~mm}]$ を 100 [\%]として, $0,60,100$ [\%]のときの結果を示す. 対偶作用力の值 は, 起立が進行するに従って変化し, Case 1, 2 共にLサイズの座位からの起立時に最も大きくなった. また, Case 1 の起立補助終了時に，全ての軸の対偶作用力が最大となった．そのときの解析結果を以下に示寸.

$\boldsymbol{f}=\{189,-962,-156,1547,-16,-699,-189,962,205,-263,205,-263,-173,848,88,-33,-134,-33,3,-33,76\}^{\mathrm{T}} \in \mathrm{R}^{21}$

これより，各軸への対偶作用力最大值は, $\left|\boldsymbol{F}_{\mathrm{A}}\right|=1.0[\mathrm{kN}],\left|\boldsymbol{F}_{\mathrm{B}}\right|=1.6[\mathrm{kN}],\left|\boldsymbol{F}_{\mathrm{C}}\right|=0.7[\mathrm{kN}],\left|\boldsymbol{F}_{\mathrm{D}}\right|=1.0[\mathrm{kN}],\left|\boldsymbol{F}_{\mathrm{E}}\right|=0.3[\mathrm{kN}]$

， $\left|\boldsymbol{F}_{\mathrm{F}}\right|=0.3[\mathrm{kN}], \quad\left|\boldsymbol{F}_{\mathrm{G}}\right|=0.9[\mathrm{kN}]$ といえる. この值を使い, 各対偶に使用する軸や軸受の設計を行い, 材質 SUS304 , 安全率 3 とした場合, 軸径は B : $14[\mathrm{~mm}], \mathrm{A}, \mathrm{C}, \mathrm{D}, \mathrm{G}: 12[\mathrm{~mm}], \mathrm{E}, \mathrm{F}: 10[\mathrm{~mm}]$ とした。また, 対偶 $\mathrm{G}$ 一 の入力トルク $\tau$ は，仰臥位から立位への変形開始時が最大であり，352[N・m]が必要であった。この值を基にアク チュエータを選定し，現在試作機を製作中である.

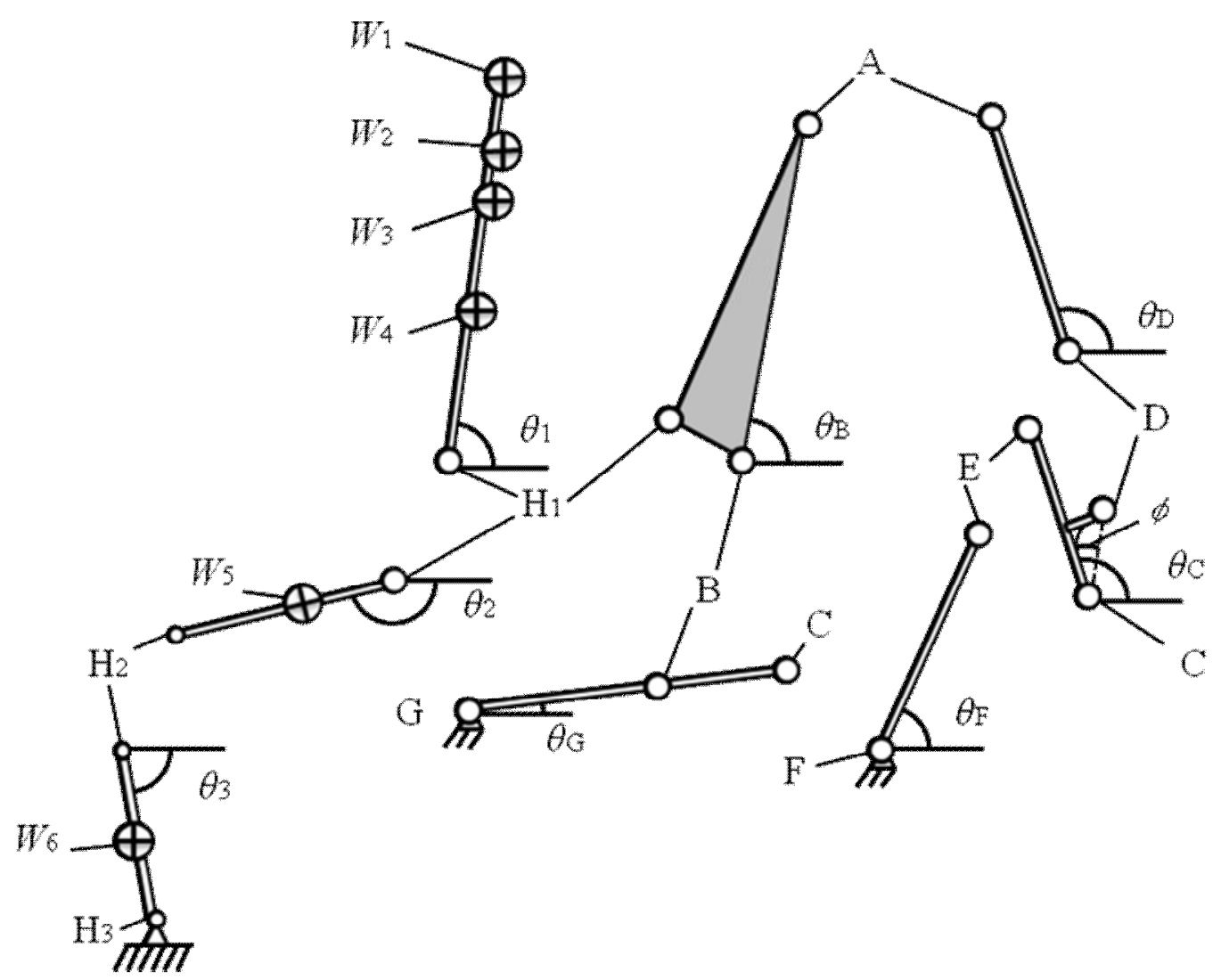

Fig. 12 Free body diagram for the apparatus and user 


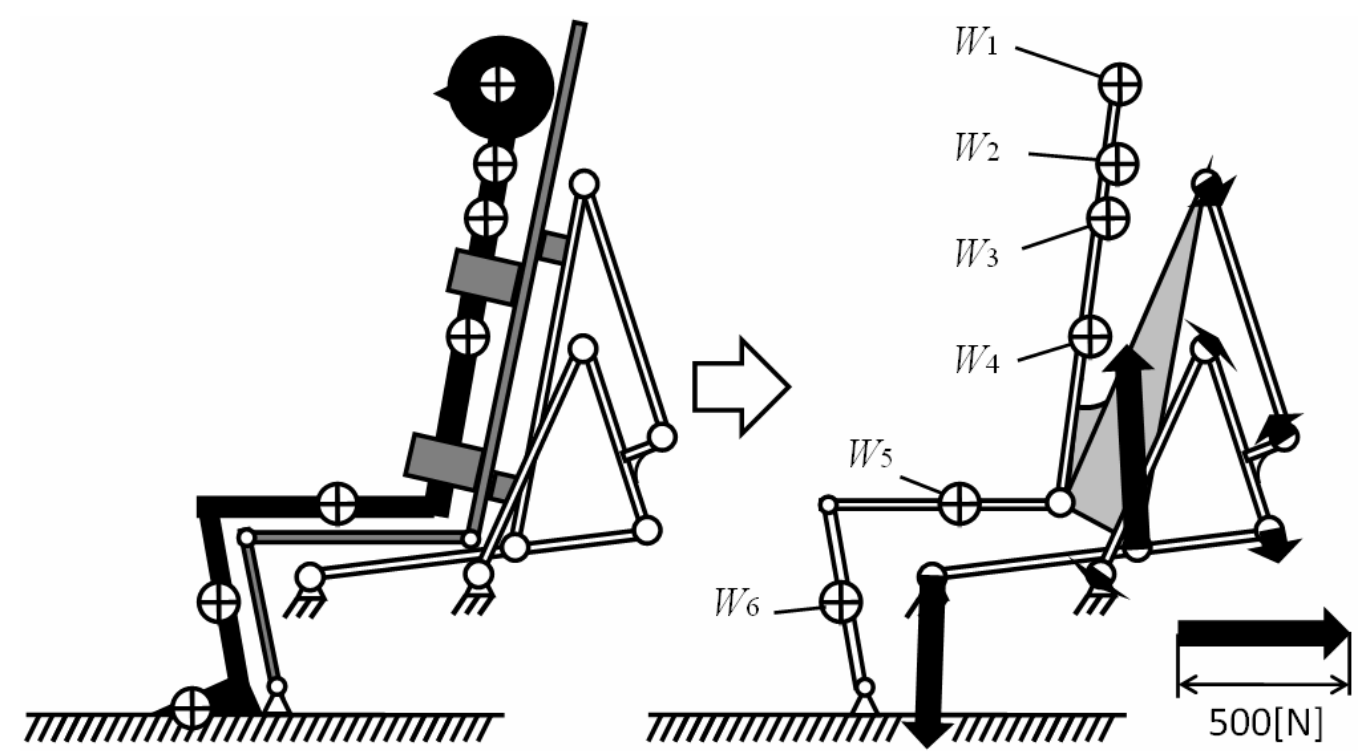

(a) Calculation model for the apparatus and user
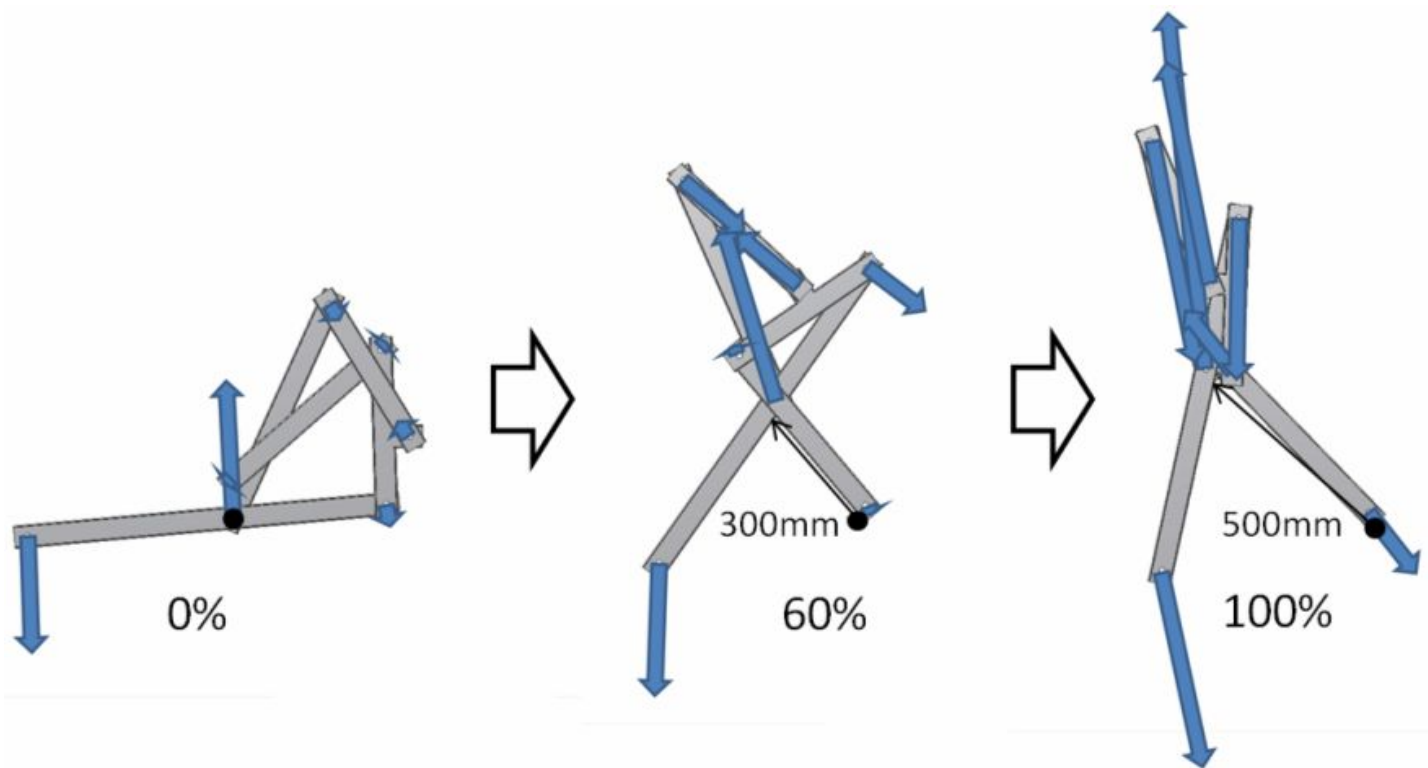

(b) Assistance from sitting to standing
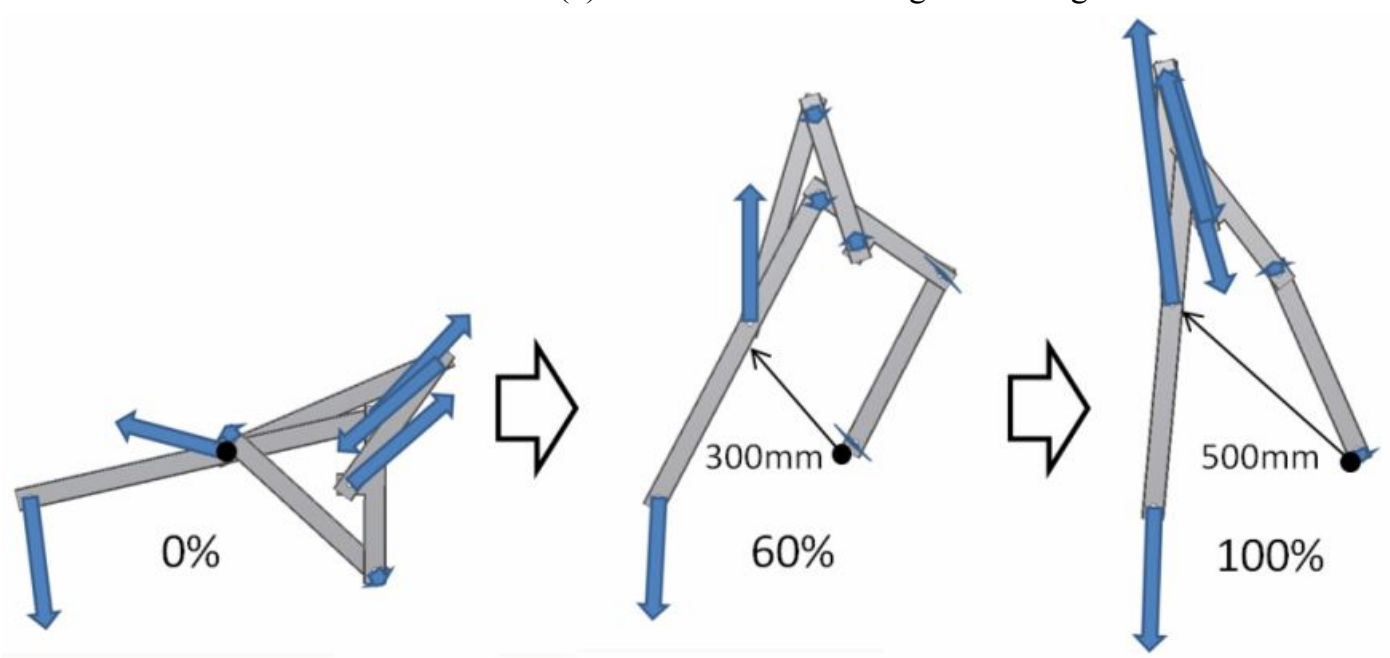

(c) Assistance from lying posture to standing

Fig. 13 Variation of each bearing load of the mechanism (Case 1) 


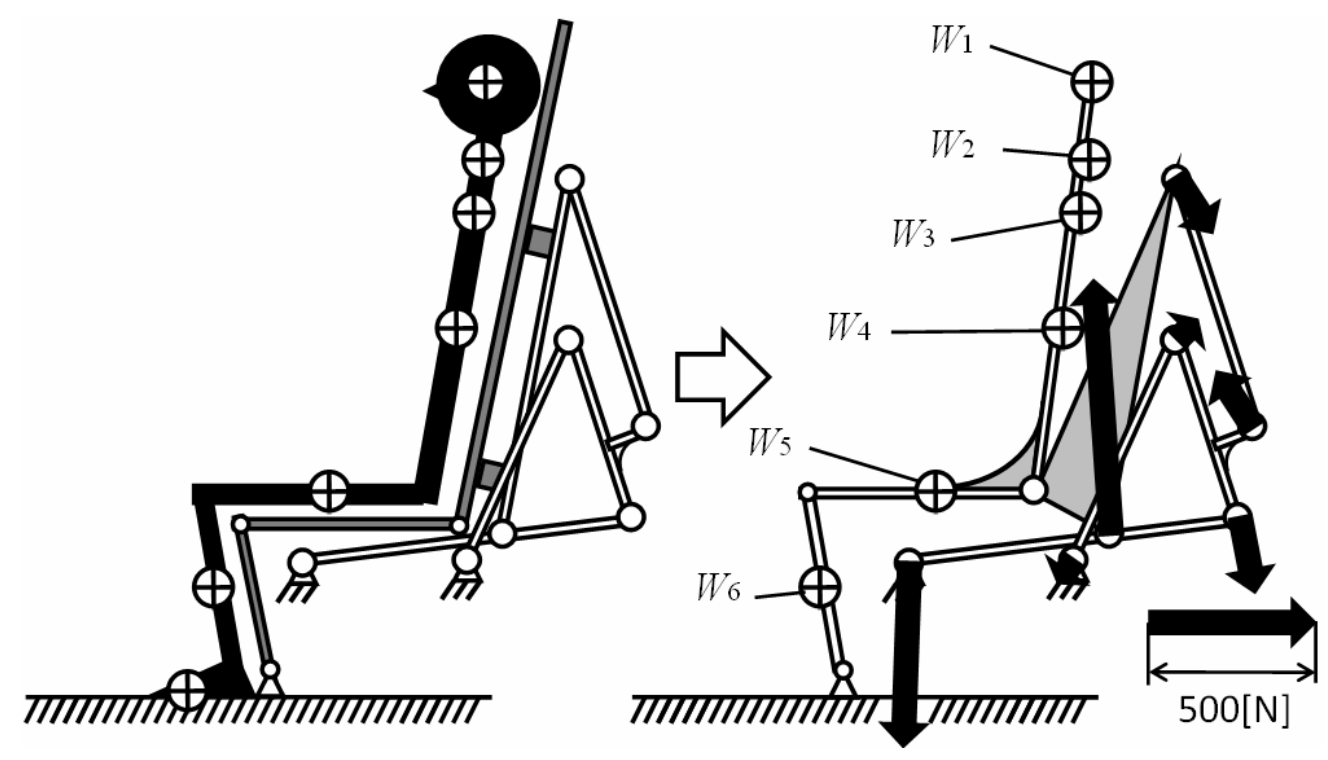

(a) Calculation model for the apparatus and user

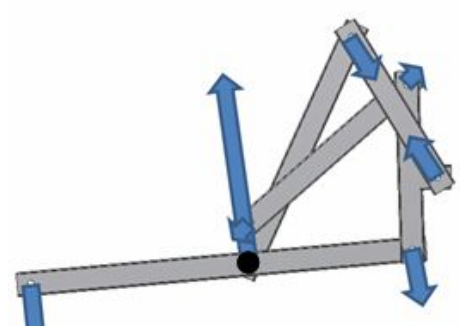

$0 \%$
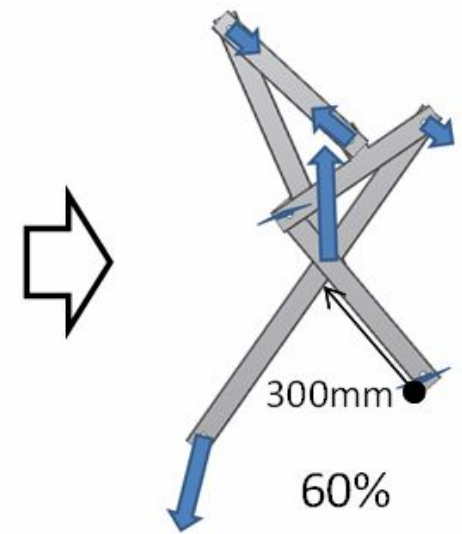

(b) Assistance from sitting to standing
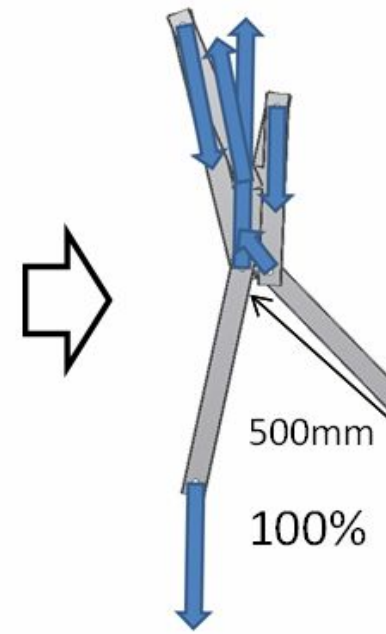

Fig. 14 Variation of each bearing load of the mechanism (Case 2)

\section{6. 起立補助効果の理論解析}

前傾起立・仰臥位型機構（機構 II ）を用いた起立補助機を使用して起立したときの人体への補助効果を確認す るため, 使用者の各関節の出力トルクを静的に算出した。一方，補助がない状態での健常な高齢者の起立中の関 節角度計測值 ${ }^{(7)}$ から各関節トルクを求め, 装置使用時の值と比較した。前述の人体モデル（図 9）を用い, 股関

節（図 9 の $\mathrm{H}_{1}$, 角度 $\theta_{1}$, トルク $\tau_{1}$ ）, 膝関節（図 9 の $\mathrm{H}_{2}$, 角度 $\theta_{2}$, トルク $\tau_{2}$ ）にかかる各トルクを式(2), (3) と して求めた。

$$
\begin{aligned}
& \tau_{1}=W_{1} l_{\mathrm{H}_{1} \mathrm{~W}_{1}} \cos \theta_{1}+W_{2} l_{\mathrm{H}_{1} \mathrm{~W}_{2}} \cos \theta_{1}+W_{3} l_{\mathrm{H}_{1} \mathrm{~W}_{3}} \cos \theta_{1}+W_{4} l_{\mathrm{H}_{1} \mathrm{~W}_{4}} \cos \theta_{1} \\
& \tau_{2}=W_{5} l_{\mathrm{H}_{2} \mathrm{~W}_{5}} \cos \theta_{2}+l_{\mathrm{H}_{1} \mathrm{H}_{2}} \cos \theta_{2}\left(W_{2}+W_{3}+W_{4}+W_{5}\right)+\tau_{1}
\end{aligned}
$$

一方，装置使用時のトルクの值は，高齢者の平均身長から身長 $155[\mathrm{~cm}]$ 向け M サイズを使用したと仮定して計 算した. 各変数の值は文献 ${ }^{(5)(6)}$ を用いて $\left\{l_{\mathrm{H} 1 \mathrm{~W} 1}, l_{\mathrm{H} 1 \mathrm{~W} 2}, l_{\mathrm{H} 1 \mathrm{~W} 3}, l_{\mathrm{H} 1 \mathrm{~W} 4}, l_{\mathrm{H} 2 \mathrm{~W} 5}, l_{\mathrm{H} 1 \mathrm{H} 2}\right\}=\{0.61,0.47,0.46,0.26,0.21$, $0.37\}[\mathrm{m}], \quad\left\{W_{1}, W_{2}, W_{3}, W_{4}, W_{5}\right\}=\{23,17,170,250,28\}[\mathrm{N}]$ とし，このときの $\theta_{1}, \theta_{2}$ は, 装置によって起立 
補助されているときの股関節および膝関節角度とした. 結果を図 15 に示寸. 足長寸法から爪先および踵の位置を 求め, その間を足底面（2 次元モデルのため前後幅）とし，足底面上に重心がある場合を実線，ない場合を破線 で示す. 図 15 より，装置使用時のほうが若干早く足底面上に重心が移動しているが，起立の安定性を考慮すると 望ましい傾向である.また, 何も補助がないときの股関節トルクは最大約 $75[\mathrm{~N} \cdot \mathrm{m}]$, 膝関節トルクは最大約 $220[\mathrm{~N} \cdot$ $\mathrm{m}]$ に対し, 補助時の股関節トルクは最大約 $40[\mathrm{~N} \cdot \mathrm{m}]$, 膝関節トルクは最大約 $170[\mathrm{~N} \cdot \mathrm{m}]$ に低減している.すなわ ち，ピーク時の比較で股関節は 47 [\%]，膝関節トルクは 22 [\%]を装置が補助することができる. 本装置を使用す ることにより，安定性が高くかつ楽に起立することができるため，億劫になりがちであった様々な日常生活に積 極的に取り組み，高齢者の QOL 向上に大いに貢献すると考えられる.

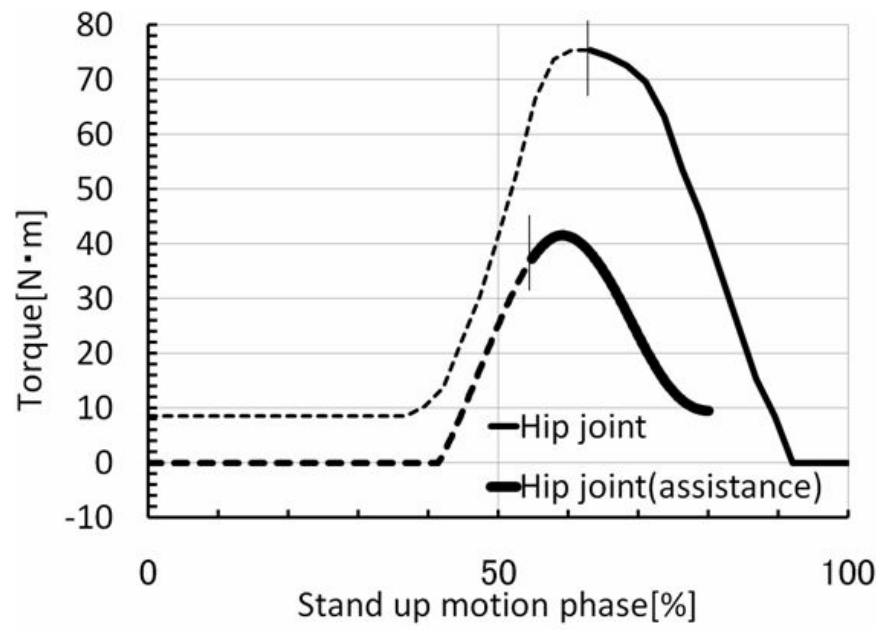

(a) Hip joint

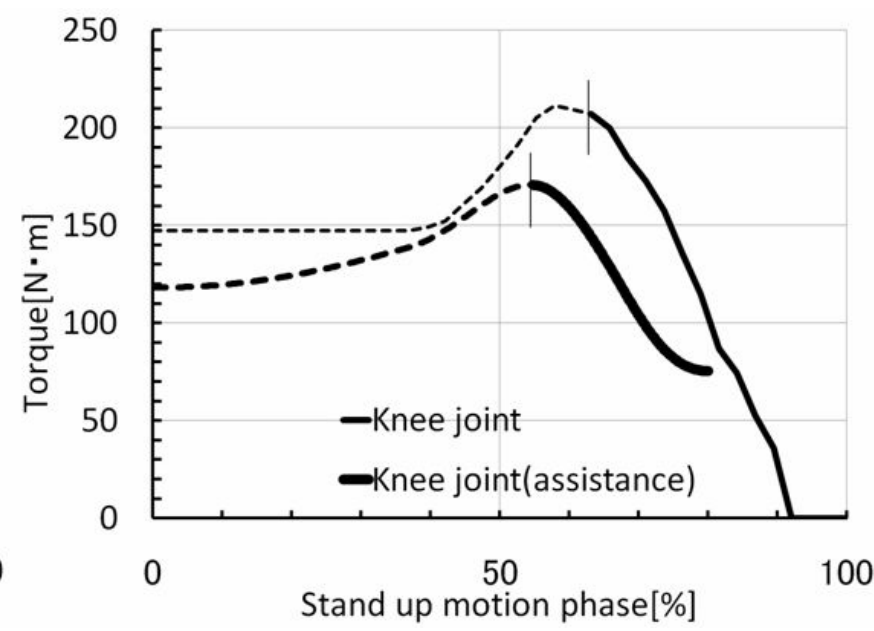

(b) Knee joint

Fig. 15 Comparison data of each calculated joint torque between assistance and without assistance the apparatus

\section{7. 結 言}

小型化可能な前傾起立・仰臥位型機構を提案し，使用者の関節の負担を軽減した起立補助が可能なリンク長を 求めた. 装置を使用して起立したときの股・膝関節トルク変化を静的に求め，何も補助がなく起立したときの姿 勢計測結果からの值と比較し, 股関節は約 4 割, 膝関節は約 2 割の補助が可能であることを計算上で確認した. 今後, 本機構の特徵を活かした起立補助椅子の試作と動作確認を行い，また，インクルーシブデザインのコンセ プトを取り入れ，高齢者・患者の方々にヒヤリングを行いながら実用化を目指す。

\section{謝 辞}

本研究の解析にあたり, 芝浦工業大学学生 矢島智之君にご協力頂きました。厚く御礼申し上げます.

\section{文 献}

（1）鈴木勇二，原田健司，起立補助装置付き車椅子，特許公開番号 P2002-78742 (2000).

（2）芝田耕蔵，リクライニング可能な起立補助椅子，特許公開番号 P2007-14459A (2005).

(3) Papa, E., Cappozzo, A., "Sit-to-stand motor strategies investigated in able-bodied young and elderly subjects", Journ al of Biomechanics, No. 33, (2000), pp. 1113-1122.

(4) Tanaka, E., Ikehara, T., Kontani, M., Hashimoto, K., and Akiyama, T., "Development of a Getting up Assistance Mechanism Supports Waist Motion”, ICMDT2009, Jeju Island, Korea, (2009), pp.196.

（5）河内まき子，横山一也，山下樹里，横井孝志，小木元，吉岡松太郎，渥美浩章，堀田明裕，“設計のための人体寸 法デー夕集”, 生命工学工業技術研究所報告 Vol. 2, No. 1, ISSN 0919-5351, (1996), 生命工学工業技術研究所.

（6）中村隆一, 斎藤宏, 長崎浩, “基礎運動学” , 第 6 版 4 刷, (2007), pp. 334-335, 医歯薬出版.

(7) 中島康博, 安河内義明, 綿貫幸宏, 武田秀勝, 橋本伸也, 田中敏明, 小島悟, 武田涼子, 伊福部達, 井野秀一, 敦 
賀健志，“日常生活動作の生体工学的調査研究”，北海道立工業試験場報告, No. 296, (1997), pp.195-199.

(8) 江原義弘, 山本澄子, “ボディダイナミクス入門 立ち上がり動作の分析”, (2001), pp.5-16, 医歯薬出版.

（9）大森圭貢, 横山仁志，青木詩子，笠原美千代，平木幸治，山崎裕司，笹益雄，“高齢患者における等尺性膝伸展筋 力と立ち上がり能力の関連”, 理学療法学, Vol. 31, No. 2, (2004), pp.106-112.

(10) Knapik, J. J., Wright, J. E., Mawdsley, R. H., and Braun, J., "Isometric, Isotonic, and isokinetic torque for variatio ns in four muscle groups through a range of joint motion", Archives of Physical Medicine and Rehabilitation, Vol. 63 No.6, (1983), pp. 938-947. 